\title{
Transformation of logwood combustion emissions in a smog chamber: formation of secondary organic aerosol and changes in the primary organic aerosol upon daytime and nighttime aging
}

\author{
Petri Tiitta $^{1}$, Ari Leskinen ${ }^{2,3}$, Liqing Hao ${ }^{2}$, Pasi Yli-Pirilä ${ }^{1,2}$, Miika Kortelainen ${ }^{1}$, Julija Grigonyte ${ }^{1}$, Jarkko Tissari ${ }^{1}$, \\ Heikki Lamberg ${ }^{1}$, Anni Hartikainen ${ }^{1}$, Kari Kuuspalo ${ }^{1}$, Aki-Matti Kortelainen ${ }^{2}$, Annele Virtanen ${ }^{2}$, \\ Kari E. J. Lehtinen ${ }^{2,3}$, Mika Komppula ${ }^{3}$, Simone Pieber ${ }^{4}$, André S. H. Prévôt ${ }^{4}$, Timothy B. Onasch ${ }^{5}$, \\ Douglas R. Worsnop ${ }^{5}$, Hendryk Czech $^{6}$, Ralf Zimmermann ${ }^{6,7,8}$, Jorma Jokiniemi ${ }^{1}$, and Olli Sippula ${ }^{1,8}$ \\ ${ }^{1}$ Department of Environmental and Biological Sciences, University of Eastern Finland, P.O. Box 1627, \\ 70211 Kuopio, Finland \\ ${ }^{2}$ Department of Applied Physics, University of Eastern Finland, P.O. Box 1627, 70211 Kuopio, Finland \\ ${ }^{3}$ Finnish Meteorological Institute, P.O. Box 1627, 70211 Kuopio, Finland \\ ${ }^{4}$ Laboratory of Atmospheric Chemistry, Paul Scherrer Institute, Villigen, Switzerland \\ ${ }^{5}$ Aerodyne Research, Inc., Billerica, MA 08121, USA \\ ${ }^{6}$ Joint Mass Spectrometry Centre, University at Rostock, Institut für Chemie, Lehrstuhl für Analytische Chemie, \\ Dr.-Lorenz-Weg 1, 18059 Rostock, Germany \\ ${ }^{7}$ Joint Mass Spectrometry Centre, Cooperation Group Comprehensive Molecular Analytics, \\ Helmholtz Zentrum München, Germany \\ ${ }^{8}$ Helmholtz Virtual Institute of Complex Molecular Systems in Environmental Health (HICE), Aerosols and Health, \\ Neuherberg, Germany
}

Correspondence to: Petri Tiitta (petri.tiitta@uef.fi)

Received: 19 April 2016 - Published in Atmos. Chem. Phys. Discuss.: 2 May 2016

Revised: 24 September 2016 - Accepted: 11 October 2016 - Published: 28 October 2016

\begin{abstract}
Organic aerosols (OA) derived from small-scale wood combustion emissions are not well represented by current emissions inventories and models, although they contribute substantially to the atmospheric particulate matter (PM) levels. In this work, a $29 \mathrm{~m}^{3}$ smog chamber in the ILMARI facility of the University of Eastern Finland was utilized to investigate the formation of secondary organic aerosol (SOA) from a small-scale modern masonry heater commonly used in northern Europe. Emissions were oxidatively aged in the smog chamber for a variety of dark (i.e., $\mathrm{O}_{3}$ and $\mathrm{NO}_{3}$ ) and $\mathrm{UV}$ (i.e., $\mathrm{OH}$ ) conditions, with $\mathrm{OH}$ concentration levels of $(0.5-5) \times 10^{6}$ molecules $\mathrm{cm}^{-3}$, achieving equivalent atmospheric aging of up to $18 \mathrm{~h}$. An aerosol mass spectrometer characterized the direct OA emissions and the SOA formed from the combustion of three wood species (birch, beech and spruce) using two ignition processes (fast
\end{abstract}

ignition with a VOC-to- $\mathrm{NO}_{x}$ ratio of 3 and slow ignition with a ratio of 5).

Dark and UV aging increased the SOA mass fraction with average SOA productions 2.0 times the initial OA mass loadings. SOA enhancement was found to be higher for the slow ignition compared with fast ignition conditions. Positive matrix factorization (PMF) was used to separate SOA, primary organic aerosol (POA) and their subgroups from the total OA mass spectra. PMF analysis identified two POA and three SOA factors that correlated with the three major oxidizers: ozone, the nitrate radical and the $\mathrm{OH}$ radical. Organonitrates (ONs) were observed to be emitted directly from the wood combustion and additionally formed during oxidation via $\mathrm{NO}_{3}$ radicals (dark aging), suggesting small-scale wood combustion may be a significant ON source. POA was oxidized after the ozone addition, forming aged POA, and after $7 \mathrm{~h}$ of aging more than $75 \%$ of the original POA was trans- 
formed. This process may involve evaporation and homogeneous gas-phase oxidation as well as heterogeneous oxidation of particulate organic matter. The results generally prove that logwood burning emissions are the subject of intensive chemical processing in the atmosphere, and the timescale for these transformations is relatively short, i.e., hours.

\section{Introduction}

Small-scale wood combustion emits large amounts of submicron black carbon (BC), organic aerosol (OA; e.g., Lanz et al., 2010; Crippa et al., 2014), polycyclic aromatic hydrocarbons (PAHs; e.g., Orasche et al., 2012; Eriksson et al., 2014; Bruns et al., 2015) and gaseous pollutants, such as $\mathrm{NO}_{x}$ and volatile organic compounds (VOCs; e.g., McDonald et al., 2000) into the atmospheric boundary layer. These emissions cause adverse health effects, reduced visibility and affect the climate. The main properties of soot particles, which are mixtures of elemental carbon, organic matter and inorganic species (ash), may change significantly due to coatings formed by atmospheric aging of emissions. The aging processes have been shown to affect particle hygroscopicity and scattering (e.g., Cappa et al., 2012) and their toxicological properties (e.g., genotoxicity; Nordin et al., 2015). Thus, atmospheric aging processes are likely to significantly affect the key properties of combustion emissions with respect to health and climate. A better understanding of the formation processes of aerosol during aging in polluted air and combustion plumes is necessary for assessing atmospheric influence of combustion aerosol and their health effects.

The organic species emitted from wood combustion are either in the gas phase or condensed phase which is mainly present as a layer of adsorbed/condensed organic matter on primary particles. These primary particles are mainly black carbon (BC) agglomerates in small-scale batch-wise operated appliances (Torvela et al., 2014; Leskinen et al., 2014). The condensed coatings on BC particles consist of a complex mixture of compounds formed via the thermal degradation of wood polymers and their further reaction products. These include monosaccharide anhydrides, methoxyphenols, polycyclic aromatic hydrocarbons (PAHs), functionalized PAHs and carboxylic acids (Hayes et al., 2011; Orasche et al., 2013) with different volatilities (i.e., semi-volatile, intermediate-volatile and low-volatile particles). Semi- and intermediate-volatile compounds favor partitioning into the gas phase when diluted or exposed to higher temperatures (e.g., Donahue et al., 2006; Kroll and Seinfeld, 2008). Due to the presence of semi- and low-volatile organics in the emissions, the freshly emitted particles from wood combustion are coated with organic matter (Tissari et al., 2008; Torvela et al., 2014), although the coating is likely to substantially increase due to the condensation of secondary organic matter formed either from anthropogenic or from biogenic organic precursor gases in the atmosphere (e.g., Akagi et al., 2012).

VOCs can undergo chemical transformation by three major oxidizers: ozone, the $\mathrm{OH}$ radical and the nitrate radical (e.g., Kroll and Seinfeld, 2008; Chacon-Madrid and Donahue, 2011). When $\mathrm{OH}$ concentrations are low, ozone and/or nitrate radicals dominate the homogenous oxidation of VOCs to form less-volatile organic compounds; for example, double bonds of alkenes may be broken by ozonolysis to produce functionalized lower-vapor-pressure products compared to the VOC precursors or fragment to smaller gas-phase VOCs. When sufficient $\mathrm{UV}$ radiation is available, $\mathrm{OH}$ radicals are produced by photolysis and dominate the oxidation of VOCs because of their high reactivity. These atmospheric oxidation reactions generate products with lower volatility which condense on the existing soot agglomerates, forming secondary organic aerosol (SOA). If the condensation sink is sufficiently small after dilution in clean air, new particle formation can also occur.

The emission regulations in the EU (EU commission regulation 2015/1185) focus exclusively on the primary aerosol emissions and neglect the formation of SOA, which may result in ineffective legislation and actions when aiming to reduce small-scale combustion emissions. There have been many studies about primary emissions from different combustion appliances and fuel types, yielding relatively reliable estimates on the primary emission factors from smallscale wood combustion (e.g., Sippula et al., 2007; Lamberg et al., 2011; Tissari et al., 2008). Moreover, recent online aerosol chemical composition measurements have improved the time resolution (Schneider et al., 2006; Weimer et al, 2008; Heringa et al., 2011, 2012; Elsasser et al., 2013; Leskinen et al., 2014; Kortelainen et al., 2015) and have emphasized the importance of combustion appliance type and wood quality as well as operational practices of combustion appliances on particulate matter (PM) emission quantity and quality.

Field studies have shown that biomass burning aerosol particles undergo significant changes in their properties that are mainly driven by atmospheric oxidation (Vakkari et al., 2014; Reid et al., 2005; Capes et al., 2008; Akagi et al., 2012). However, results from field studies are not easily comparable because of variations in uncontrolled emissions and conditions. Thus, detailed investigation of SOA formation from biomass burning processes requires well-controlled laboratory studies (e.g., Grieshop et al., 2009a). Regarding open biomass burning, the study of Ortega et al. (2013) reported SOA formation in a flow reactor from biomass burning smoke samples which were generated in an open fire chamber with 25 different types of biomass. An average SOA formation of 1.4 times the initial primary organic aerosol (POA) was observed, with SOA concentrations peaking after 3 days

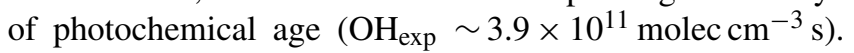
Similarly, the study of Hennigan et al. (2011) reported an average OA mass enhancement ratio of 1.7 (varying from 0.7 


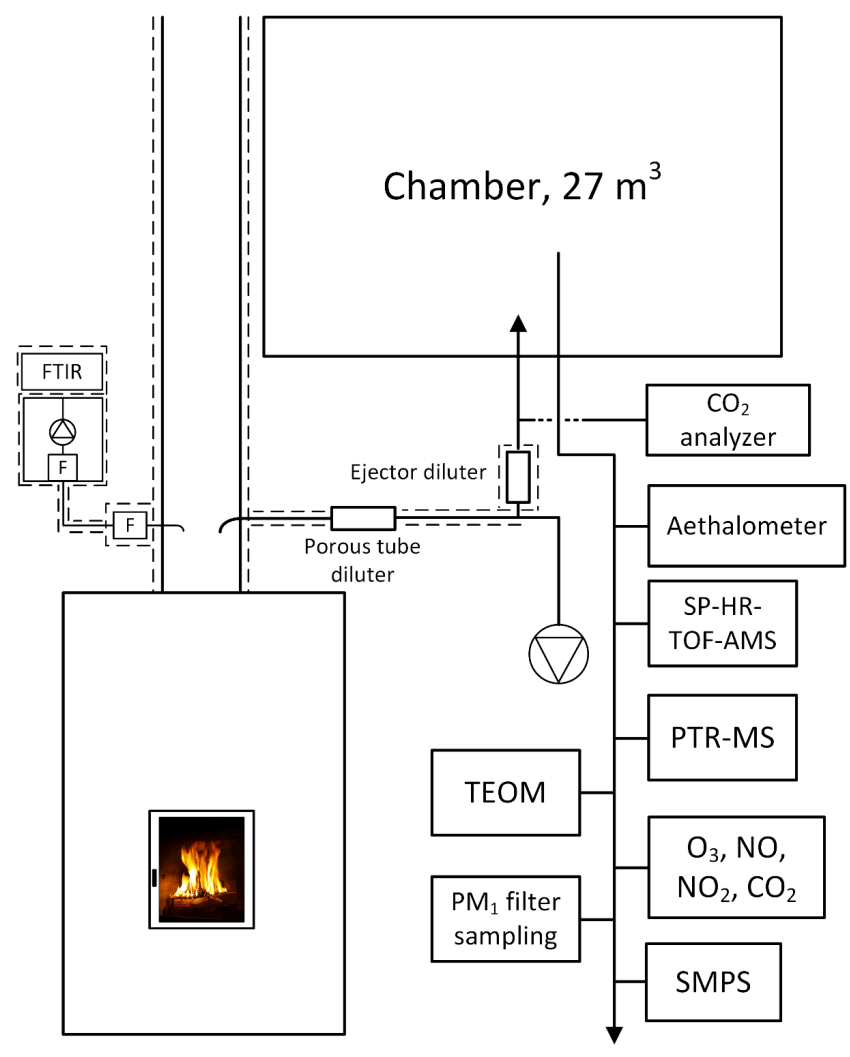

Figure 1. Experimental setup in the ILMARI combustion research facility at the University of Eastern Finland.

to 2.9) in smog chamber experiments with biomass typical in North American wildfires.

Regarding residential wood combustion processes, several laboratory studies have been conducted to determine SOA emission factors and chemical composition (e.g., Corbin et al., 2015a) using chambers or continuously operated flow reactors. Photo-oxidation experiments with wood batch combustion emissions in smog chambers have revealed that wood-burning net SOA-to-POA ratios are at least 1.5 or higher (Grieshop et al., 2009a; Heringa et al., 2011; Bruns et al., 2015). In a previous study on a logwood fired stove (Bruns et al., 2015), the emissions were aged in a $29 \mathrm{~m}^{3} \mathrm{smog}$ chamber for $4.5-16 \mathrm{~h}$, corresponding to $\mathrm{OH}$ exposures of $(0.7-2) \times 10^{11}$ molec $\mathrm{cm}^{-3} \mathrm{~s}$. They reported an OA increase by factors of 3 and 1.6 for high and low stove loadings of beech logs, respectively. They also found that the contribution of the total average PAH to the total OA was 4 and $15 \%$ for low and high loadings, respectively, and that functionalized PAHs increased with ongoing aging.

Small-scale combustion emissions have received insufficient attention until today, although this type of emission is known to be among the largest sources of OM (organic mass) and climate-active BC (e.g., Bond et al., 2004; Denier van der Gon et al., 2015; Butt et al., 2016). These emissions typically increase in cold weather because of the increased use of wood combustion, which leads, together with a suppressed atmospheric mixing layer (e.g., inversion) and relatively low emission height, to peaks in ambient boundary-layer aerosol concentrations in regions where wood burning is common (Saarikoski et al., 2008; Yli-Tuomi et al., 2015). To investigate the transformation of these emissions, the effects of both dark and photochemical aging on the emissions from wood combustion were studied in a smog chamber (Leskinen et al., 2015 ) in this work, simulating the dilution and chemical reactions occurring in a combustion plume under boundary-layer conditions. The used combustion appliance was a typical, modern northern European masonry heater (Nuutinen et al., 2014) fired with beech, birch and spruce logs. The specific aims were to (1) quantify the emission factors of SOA from a representative logwood-fired masonry heater, (2) characterize the evolution of OA chemical composition during aging and (3) investigate the effects of different oxidation mechanisms on SOA formation.

\section{Methods}

\subsection{Procedure of emission aging experiments}

Atmospheric aging processes of logwood combustion emissions were studied in the ILMARI facility of the University of Eastern Finland (http://www.uef.fi/en/web/ilmari/home). The experiments focused on investigating the effects of dark and UV-light-induced aging of residential-scale wood combustion emissions and were carried out in a $29 \mathrm{~m}^{3} \mathrm{smog}$ chamber (Leskinen et al., 2015). The experimental conditions are listed in Table 1, and the setup is presented in Fig. 1.

A modern heat-storing masonry heater with a staged combustion air supply (Leskinen et al., 2014; Reda et al., 2015) was used as the combustion source. In each experiment, $2.5 \mathrm{~kg}$ of wood $\operatorname{logs}$ (spruce, Picea abies; birch, Betula pubescens; and beech, Fagus sylvatica) was burned with combustion initiated from "cold start"; i.e., the firebox was at room temperature. Each combustion experiment included the ignition, flaming combustion and residual char burning phases. Ten logs $(\sim 235 \mathrm{~g}$ each) were laid crosswise with $150 \mathrm{~g}$ of smaller wood pieces as kindling on top. The combustion was initiated by igniting a batch of wood sticks, serving as kindling, on top of the wood batch. Low pressure in the stack was adjusted with a flue gas fan and dampers to $12.0 \pm 0.5 \mathrm{~Pa}$ below ambient pressure. The moisture contents of the wood logs were 7.2, 7.4 and 9.0\%, for birch, spruce and beech, respectively (see Reda et al., 2015 for details), which agrees with a kiln-dried commercial logwood quality. The ignition of the wood batch was carried out in two different ways: (1) smaller kindling size resulted in faster ignition of the main batch and (2) larger kindling size (double) resulted in slower ignition of the main batch (Table 1). The mass of kindling was $150 \mathrm{~g} /$ ignition. The gaseous emissions from the raw exhaust gas were measured online with a 
Table 1. Overview of the experimental parameters in the smog chamber experiments: VOC-to- $\mathrm{NO}_{x}$ ratio $\left(\mathrm{VOC} / \mathrm{NO}_{x}\right.$; $\left.\mathrm{ppbv}_{\mathrm{ppbv}}{ }^{-1}\right)$,

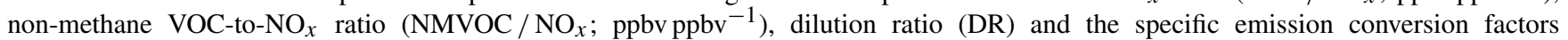
(ECFs; $\mathrm{m}^{3} \mathrm{~kg}^{-1}$ fuel) determined for each logwood combustion experiment.

\begin{tabular}{llllcccc}
\hline Exp. & Wood & Function & Ignition & VOC $/ \mathrm{NO}_{x}$ & ${\mathrm{NMVOC} / \mathrm{NO}_{x}}^{\mathrm{DR}}$ & ECF $^{\mathrm{a}}$ \\
\hline 1A & Beech & Dark & Fast & 2.6 & 1.2 & 372 & 7.8 \\
2A & Birch & Dark & Fast & 1.3 & 0.6 & 456 & 9.1 \\
3A & Spruce & Dark & Fast & 2.7 & 1.2 & 313 & 6.9 \\
1B & Spruce & Dark + UV & Fast & 3.1 & 1.3 & 259 & 5.8 \\
2B & Spruce & Dark + UV & Slow & 4.9 & 2.3 & 245 & 6.2 \\
3B & Spruce & Dark + UV + H & Fast & 4.0 & 1.5 & 245 & 6.0 \\
4B & Spruce & UV & Fast & 2.7 & 1.1 & 266 & 6.1 \\
5B & Spruce & UV & Slow & 4.8 & 2.2 & 229 & 5.8 \\
\hline
\end{tabular}

${ }^{\mathrm{a}}$ The ECF calculations followed Reda et al. (2015). ${ }^{\mathrm{b}} \mathrm{HONO}$ addition.

multicomponent FTIR analyzer (Gasmet Technologies Inc.), including $\mathrm{CO}_{2}, \mathrm{CO}, \mathrm{NO}, \mathrm{NO}_{2}, \mathrm{CH}_{4}$ and 15 typical hydrocarbon compounds (Table S1, Figs. S1-S3 in the Supplement) for wood combustion emissions. In addition, the analyzer was equipped with an $\mathrm{O}_{2}$ sensor. The combustion exhaust was sampled with a system in which the sample is drawn though a PM10 pre-cyclone, a heated probe $\left(150^{\circ} \mathrm{C}\right)$, and then diluted in two stages. The primary dilution was conducted with a porous tube diluter, and the secondary dilution with an ejector diluter (DI-1000, Dekati Ltd.). Clean air at ambient temperature was used as the dilution gas, and the sampling line dilution ratio was adjusted to 24-31 for samples entering the chamber. The sampling was performed in a pre-filled chamber with clean air such that the total chamber dilution ratios ranged from 229 to 456 (Table 1). The sampling lines from the porous tube diluter to the environmental chamber were heated to $100^{\circ} \mathrm{C}$ and externally insulated to reduce line losses. The dilution ratios in the sampling line and in the chamber were monitored by following the $\mathrm{CO}_{2}$ concentrations of the raw combustion gas, pre-diluted sample (ABB $\mathrm{CO}_{2}$-analyzer), and in the chamber (Vaisala GMP 343, Finland). The smog chamber is a collapsible Teflon bag chamber that is equipped with 47 blacklight lamps $(350 \mathrm{~nm}$, Sylvania F40 W/350 BL; Leskinen et al., 2015). Before each experiment, the chamber was emptied for cleaning, filled with purified air (Model 737-250, Aadco Instruments Inc., USA) with a relative humidity set to approximately $50 \%$ (Model FC125-240-5MP, Perma Pure LLC., USA) and finally flushed overnight. The average temperature and relative humidity in the chamber during each experiment was $18 \pm 2{ }^{\circ} \mathrm{C}$ and $60 \pm 5 \%$, respectively.

In the first set of experiments, the POA and dark aging products of different wood species were compared (Exp. 1A3A). These experiments were carried out with spruce, birch and beech logs. In the second set of experiments, a detailed investigation was executed with spruce $\operatorname{logs}$ as fuel (Exp. 1B-5B); these experiments included aging both via dark aging and via UV-light-induced photochemical reac- tions. In experiments $1 \mathrm{~B}-3 \mathrm{~B}$, dark aging was followed by $\mathrm{OH}$ exposure (photo-oxidation), whereas simultaneous $\mathrm{O}_{3}$ and $\mathrm{OH}$ exposure was conducted in experiments $4 \mathrm{~B}$ and 5B. The experiments began with the filling of the chamber with a prediluted sample of the first batch of logwood combustion emissions (35 min). During a stabilization period ( $40 \mathrm{~min}$ ) followed by filling, the sample was mixed; the organics presumably reached an equilibrium based on the $\mathrm{CO}_{2}$ levels and wall-loss-corrected OA time trends. After the stabilization, $1 \mu \mathrm{L}$ of butanol-d9 (9 ppb) was injected into the chamber to determine the sample $\mathrm{OH}$ exposure and photochemical age during the experiments (Barmet al., 2012). The butanol-d9 decay was monitored by a high-resolution proton transfer reaction mass spectrometer (PTR-TOF 8000, Ionicon Analytik, Innsbruck, Austria). During each experiment, all of the $\mathrm{NO}$ in the chamber was converted to $\mathrm{NO}_{2}$ by adding $\mathrm{O}_{3}$. After the full conversion, an additional $40 \mathrm{ppb}$ of $\mathrm{O}_{3}$ was added. After $3 \mathrm{~h}$ of dark aging, the UV lights were switched on and the aerosol particles were aged with UV for 3-4h (Exp. 1B-3B), corresponding to total $\mathrm{OH}$ exposures of (4-6) $\times 10^{10} \mathrm{molec}^{-3} \mathrm{~s}$. In addition, in experiment $3 \mathrm{~B}$, HONO was injected into the chamber after the dark aging to simulate HONO-rich conditions in the atmosphere. The hydroxyl $(\mathrm{OH})$ radical is one of the main reactive species in the atmospheric boundary layer; peak daytime $\mathrm{OH}$ radical concentrations are in the range of $(1-10) \times 10^{6}$ molec cm$^{-3}$ (e.g., Atkinson, 2000; Huang et al., 2014). HONO was produced by the titration of sodium nitrite $\left(\mathrm{NaNO}_{2}\right)$ solution $(1 \mathrm{wt} \%)$ into sulfuric acid $\left(\mathrm{H}_{2} \mathrm{SO}_{4}\right)$ solution $(10 \mathrm{wt} \%)$ in a glass flask equipped with a magnetic stirrer based on the method developed by Taira and Kanda (1990). The gaseous $\mathrm{HONO}$ was guided by a purified air flow of $3.0 \mathrm{~L} \mathrm{~min}^{-1}$ into the chamber. In experiments $4 \mathrm{~B}$ and $5 \mathrm{~B}$, UV lights were switched on immediately after ozone injection, corresponding to $\mathrm{OH}$ exposures of $(5-7) \times 10^{10}$ molec. $\mathrm{cm}^{-3} \mathrm{~s}$. A similar procedure was applied for all sets of experiments (1A$3 \mathrm{~A}$ and $1 \mathrm{~B}-5 \mathrm{~B})$ except the first experiments $(1 \mathrm{~A}-3 \mathrm{~A})$, which were conducted with a shorter stabilization period $(10 \mathrm{~min})$ 
before ozone addition; no injection of butanol-d9 was performed in these experiments.

\subsection{Measurements of particles and their chemical composition in the chamber}

Particle number concentrations and size distributions were measured with a scanning mobility particle sizer (SMPS, CPC 3022, TSI). $\mathrm{PM}_{1}$ filter samples were collected on $47 \mathrm{~mm}$ quartz fiber filters (Pallflex, Tissuquartz) from the chamber in the second round of experiments after the injection of the primary emissions and at the end of each period (two-three filter samples/experiment). A pre-impactor (Dekati Ltd.) with a cutoff diameter of $1 \mu \mathrm{m}$ was applied. The organic and elemental carbon were determined from quartz filter samples by a thermal optical method using a carbon analyzer from Sunset Laboratories according to the National Institute for Occupational Safety and Health (NIOSH) procedure, which is described in Sippula et al. (2007, 2009).

The soot particle aerosol mass spectrometer (SP-HR-TOFAMS; Onasch et al., 2012) was applied to measure the major fraction of submicron particles (Aerodyne Research Inc., USA). The SP-AMS is a high-resolution aerosol mass spectrometer (HR-AMS; DeCarlo et al., 2006) that is equipped with a laser vaporizer based on single-particle soot photometer technology (SP2, Droplet Measurement Technologies, CO, USA; Stephens et al., 2003). The combination of the thermal vaporizer $\left(600^{\circ} \mathrm{C}\right)$ and the continuous wave laser vaporizer $(1064 \mathrm{~nm})$ enables the study of both nonrefractory (NR-PM) and refractory light-absorbing submicron aerosol particles (R-PM, e.g., rBC). The aerodynamic lens with $100 \%$ transmission range of $75-650 \mathrm{~nm}$ (Liu et al., 2007) focuses particles into a narrow beam that crosses the laser beam vaporizing particles containing $\mathrm{rBC}(\sim 4000 \mathrm{~K})$ and subsequently onto a heated conical porous tungsten surface $\left(600^{\circ} \mathrm{C}\right)$ at the center of the ionization chamber. Vaporized molecules are ionized by electron impact $(70 \mathrm{eV})$ and detected with a high-resolution time-of-flight mass spectrometry (Tofwerk AG) in positive ion mode. The HR-TOFAMS was operated in $\mathrm{V}$-mode $(\Delta m / m \sim 2000)$ from 12 to $555 \mathrm{~m} / z$, which enables the identification, separation and quantification of typical organic and inorganic species. Two vaporizer configurations, i.e., dual laser and tungsten vaporizers and tungsten vaporizer only modes, were alternated every $60 \mathrm{~s}$; particle time-of-flight (PTOF) modes were operated for $20 \mathrm{~s} \mathrm{~min}^{-}$.

Standard mass-based calibrations were performed for the ionization efficiency in the AMS using dried and sizeselected $(300 \mathrm{~nm})$ ammonium nitrate $\left(\mathrm{NH}_{4} \mathrm{NO}_{3}\right)$ particles (Jayne et al., 2000). $\mathrm{NH}_{4} \mathrm{NO}_{3}$ calibrations allow for the determination of nonrefractory species using the standard speciesspecific relative ionization efficiencies (RIEs). Regal Black (Regal 400R Pigment Black, Cabot Corp.) particles were analyzed to determine the relative ionization efficiency for $\mathrm{rBC}$ $\left(\mathrm{RIE}_{\mathrm{rBC}}\right)$ with values of 0.16 and 0.25 for the first and sec- ond set of experiments, respectively. A detailed description of the SP-AMS is presented in Onasch et al. (2012). The aerosol mass concentrations were also corrected for the particle collection efficiency (CE). The $\mathrm{CE}$ values can be smaller than 1 because of losses in the aerodynamic inlet or on the vaporizer (tungsten) or increasing divergence in the particle beam (laser vaporizer). CEs of 0.5 and 0.6 for tungsten (Canagaratna et al., 2007) and the laser vaporizer (Willis et al., 2014), respectively, were applied in the concentration calculations. The laser vaporizer CE (0.6) was determined via direct comparison with offline elemental carbon (EC) concentrations analyzed from filter samples (20 min) during stabilization phase of experiments (i.e., before oxidation). The SP-AMS dual vaporizer mode was used to characterize the rBC (and potassium) mass loadings and chemical signatures; all other particulate chemical species (Org, $\mathrm{NO}_{3}, \mathrm{SO}_{4}, \mathrm{NH}_{4}$ and $\mathrm{Chl}$ ), specifically including all analyses of OA and SOA, were done using the standard tungsten vaporizer measurements. Therefore, all particulate measurements (other than $\mathrm{rBC}$ and $\mathrm{K}$ ) represent the standard AMS operationally defined nonrefractory portion of these chemical species (Jimenez et al., 2003). These CEs were verified by comparison with Tapered Element Oscillating Microbalance (TEOM, Thermo Scientific, model 1405) total $\mathrm{PM}_{1}$ mass. Any uncertainties with the CEs may affect the absolute concentrations of the measured species and the relative OM-to$\mathrm{rBC}$ ratios, although they are less likely to affect the SOA formation ratios, which are discussed later.

\subsection{Data analysis}

Particle wall losses (WL correction) have been characterized for decades (e.g., McMurry and Rader, 1985), although the estimation of losses of semi-volatile species remains challenging (e.g., Zhang et al., 2014; Kokkola et al., 2014; Krechmer et al., 2016; Ye et al., 2016). An incorrect estimation of the WL can cause major uncertainties in SOA yields; therefore, it must be performed carefully. The extent of WL of particles depends on several factors, e.g., the surface area-tovolume ratio, the material of the chamber, electric field and turbulence in the chamber, and particle size and charge distribution. The accuracy of the WL calculations suffers from potential changes in the SP-AMS rBC CE (Willis et al., 2014), unknown wall losses of semi-volatile species (Zhang et al., 2014) and possible changes in the effective density of soot agglomerates (Leskinen et al., 2014).

In this work, WL corrections were calculated based on the decay in refractory black carbon ( $\mathrm{rBC}$ ) concentrations measured by the SP-AMS and adjusted by the decay of elemental carbon concentrations measured by a thermal-optical method (maximum correction of $15 \%$ ). The correction based on elemental carbon concentrations was made because of the increased SP-AMS sensitivity for highly coated particles (Willis et al., 2014). The calculated $\mathrm{WL}_{\mathrm{rBC}}$,fix values agreed well with WLSMPS, which was calculated from SMPS data 
(method is described in Weitkamp et al., 2007) in experiments $4 \mathrm{~B}$ and $5 \mathrm{~B}$, whereas in $1 \mathrm{~A}-3 \mathrm{~A}$ WL $\mathrm{WMPS}_{\text {SMhibited }}$ 12-23\% higher wall losses. Higher WL corrections would lead to higher SOA-to-POA ratios. WL corrections were applied after the emissions were injected and well mixed in the chamber until the end of the experiments. The PM emissions of the analyzed chemical components were determined by multiplying the measured chamber concentrations with the chamber dilution ratio (DR, Table 1) and the specific emission conversion factor (ECF, $\mathrm{m}^{3} \mathrm{~kg}^{-1}$ fuel) determined according to the standard SFS 5624 (Reda et al., 2015).

AMS data analysis was performed with the analysis software SQUIRREL v1.55C and the standard HR-TOF-AMS data analysis software Peak Integration by Key Analysis (PIKA v1.16 C) adapted in Igor Pro 6.34 A (Wavemetrics). The AMS samples particles $10^{7}$ times more efficiently than gases (Canagaratna et al., 2007). Nonetheless, gasphase $\mathrm{CO}_{2}$ concentrations in the chamber of approximately $500 \mathrm{ppm}$ are sufficiently high to affect the AMS measurements. Thus, the influence of $\mathrm{CO}_{2}$ was corrected using time-dependent gas-phase $\mathrm{CO}_{2}$ measurements and checking corrected data using online HEPA filter samples. Highresolution mass concentrations were calculated using the HR-AMS fragmentation table (Allan et al., 2003; Jimenez et al., 2003), and j15NN isotope analysis was performed by constraining $\mathrm{j} 15 \mathrm{NN}$ with $\mathrm{N}_{2}$. The SP-AMS flow was corrected to standard temperature and pressure, which is consistent with common practice, and the data were post-corrected by the measured air beam. Elemental analysis (Aiken et al., 2007) was performed by the new method described in Canagaratna et al. (2015).

Positive matrix factorization (PMF) is a statistical tool to determine several characteristic mass spectra (i.e., factors) that best describe the overall time-dependent mass spectra by minimizing model residuals. User input is required such that the mass spectra factors still have realistic physical meaning (Paatero and Tapper, 1994; Paatero, 1997). Before the analysis, signals were exported using a peak-integration method and the new error matrix model described in Corbin et al. (2015c). The PMF Evaluation Tool v.2.08 was applied, and the standard data pre-treatment process was executed based on Ulbrich et al. (2009), including applying minimum error criteria, down-weighting weak variables based on the signal-to-noise ratio, and $m / z 44$, $\mathrm{NO}$ and $\mathrm{NO}_{2}$ and water-related peaks. The PMF analysis was performed on the combined high-resolution organic and inorganic nitrate mass spectra (Hao et al., 2014). Particulate nitrate was added to the PMF analysis because the sources of particulate organic nitrate (ON) are not well known (Fry et al., 2009, 2013; Liu et al., 2012; Rollins et al., 2012; Farmer et al., 2010). Moreover, wood combustion is an important source of gaseous nitrogen oxides that can form $\mathrm{ON}$ via nitrate radical chemistry (Rollins et al., 2012). Rotational freedom of the solution was investigated with fpeak (a parameter that is used to explorer ambiguity associated with rotations within the solution space) values between -1 and 1 to minimize the $Q / Q_{\exp }$ ratio combined with residuals (unsolved fraction), which was less than $1 \%$ in all experiments. CE and RIE of 1 is applied (standard procedure) in PMF calculations.

\section{Results}

\subsection{Primary emissions}

The total PM emissions ranged from 0.6 to $1.4 \mathrm{~g} \mathrm{~kg}^{-1}$ (Table 2) for equal wood loading, which agrees with previously reported findings (e.g., Tissari et al., 2007; Lamberg et al., 2011; Bruns et al., 2015). Birch showed the highest total emissions and largest $\mathrm{rBC}$ mass fractions. Considering only spruce emissions, the fast ignition experiments (Exp. 1B, 3B and $4 \mathrm{~B}$ ) with a lower VOC-to- $\mathrm{NO}_{x}$ ratio yielded smaller total emissions than the slow ignition cases (Exp. 2B and 5B) when the VOC-to- $\mathrm{NO}_{x}$ ratios were higher. Furthermore, it was observed in the slow ignition cases that the emissions of non-methane VOCs (NMVOCs) show a distinct peak about 8-10 min after ignition (Fig. S3), whereas fast ignition produced substantially lower peak at around $5 \mathrm{~min}$ after ignition. The ignition method has also a strong effect on the combustion rate of the whole batch. In the experiments $2 \mathrm{~B}$ and $5 \mathrm{~B}$ there were still yellow flames after 35 min (considered as a length of the batch), while in the experiments $1 \mathrm{~B}, 3 \mathrm{~B}$ and $4 \mathrm{~B}$, the flaming phase ended already at around $28 \mathrm{~min}$ from ignition and the rest of the combustion process included only char burning without visible flames.

The mass spectra of the $\mathrm{rBC}\left(\mathrm{C}_{x}^{+}\right)$remained constant for all of the aging experiments, with dominating signals at low carbon cluster numbers $\left(\mathrm{C}_{1}^{+}\right.$to $\left.\mathrm{C}_{5}^{+}\right)$. The $\mathrm{C}_{1}^{+}: \mathrm{C}_{3}^{+}$ratio was approximately 0.6 , which is similar to the values obtained from a propane diffusion flame (CAST "black") produced by a combustion aerosol standard burner (Corbin et al., 2014). Thus, the logwood materials used in this work (spruce, birch and beech) suggest a similar elemental carbon chemical structure as obtained by Corbin (2014) and that the microstructural properties do not change remarkably during atmospheric aging.

In contrast to the elemental carbon, OA on soot agglomerates undergoes intense changes upon oxidation. OA concentrations were well correlated with the SMPS volume ( $R=0.8$ ) over the range of oxidation conditions, with a better correlation during dark aging than during UV aging. OA was observed in the same particle size range as $\mathrm{rBC}$, which confirms an increase in organic coatings on soot particles upon aging (internally mixed). The mass ratio of the OA fraction to the $\mathrm{rBC}$ ranged from 0.2 (fresh emissions) to 0.4 (aged emissions; Table 2). The relatively efficient burning conditions in modern masonry heaters and the applied ignition method, in which the ignition is performed on the top of the wood batch with wood sticks, decreased the OA fraction in this study compared to studies conducted using conventional 
Table 2. PM emissions ( $\mathrm{mg} \mathrm{kg}^{-1}$ fuel) of the AMS species and ratios of OA to rBC and PM (TEOM) to AMS total.

\begin{tabular}{lrrrrrrrrc}
\hline Exp. & $\mathrm{OA}$ & $\mathrm{rBC}$ & $\mathrm{NO}_{3}$ & $\mathrm{SO}_{4}$ & $\mathrm{NH}_{4}$ & $\mathrm{Chl}$ & Total & OA / BC & PM / Total \\
\hline 1A & 209.8 & 751.1 & 40.8 & 27 & 0.5 & 0.9 & 1029 & 0.28 & - \\
2A & 221.2 & 1133 & 37.1 & 8.8 & 0.2 & 2.0 & 1403 & 0.20 & - \\
3A & 105.9 & 512.2 & 22.5 & 6.7 & 0.8 & 1.5 & 649.6 & 0.21 & - \\
1B & 157.7 & 513.7 & 42.4 & 8.7 & 0.6 & 0.6 & 723.7 & 0.31 & 1.2 \\
2B & 228.3 & 655.5 & 43.0 & 5.9 & 0.6 & 0.7 & 934.0 & 0.35 & 1.3 \\
3B & 149.5 & 572.2 & 34.1 & 6.3 & 0.4 & 0.7 & 763.1 & 0.26 & 1.2 \\
4B & 118.3 & 422.0 & 42.7 & 6.7 & 1.2 & 0.7 & 591.6 & 0.28 & 1.3 \\
5B & 207.1 & 546.0 & 35.9 & 7.4 & 0.3 & 1.1 & 797.9 & 0.38 & 1.3 \\
\hline
\end{tabular}

batch combustion appliances (Tissari et al., 2009). Furthermore, well-dried wood fuel was used, which is not always the case in reality. However, the experiments represent an upper limit for the selected combustion appliance and fuel combination because the first batch of logwood combustion typically generates higher emissions than subsequent batches (Leskinen et al., 2014).

The potassium $(\mathrm{K})$ concentration, which is one of the main ash components of logwood combustion (Tissari et al., 2007), was measured using the SP-AMS dual vaporizer mode; clear $\mathrm{K}$ and $\mathrm{j} 41 \mathrm{~K}$ signals were observed. However, the potassium emissions are not reported here because potassium analysis using an AMS is subject to additional uncertainties caused by the non-standard ionization of potassium leading to significant variation between instruments (Drewnick et al., 2006; Slowik et al., 2010). Using $\mathrm{RIE}_{K}$ of 10 (Slowik et al., 2010), the estimated potassium emissions were 4.1, 0.9 and $0.4 \%$ of the $\mathrm{PM}_{1}$ emissions for spruce, beech and birch, respectively. Potassium emitted from wood combustion appears mainly in the form of $\mathrm{K}_{2} \mathrm{SO}_{4}, \mathrm{KCl}$ and $\mathrm{K}_{2} \mathrm{CO}_{3}$ (Sippula et al., 2007), which are expected to be externally mixed with soot agglomerates (Torvela et al., 2014). The SMPS data showed that the median diameter of soot agglomerates increased substantially from $70-120$ to $150-220 \mathrm{~nm}$ during aging (Figs. S4 and S5). The number concentrations were in the range of 2.8-6.5 $\times 10^{4} \mathrm{~cm}^{-3}$, and the mass closure of the AMS species measurements agreed relatively well with the total PM mass measured with the TEOM (Table 2).

\subsection{SOA formation}

Figure 2 illustrates the formation of SOA during aging in a smog chamber together with particulate $\mathrm{NO}_{3}$ and $\mathrm{SO}_{4}$, ozone and $\mathrm{NO}_{x}$ concentrations. The results are summarized in Table 3. SOA was calculated using WL-corrected OA concentrations by subtracting the POA mass (average OA at the end of stabilizing phase A). The wall loss correction method is described in Sect. 2.3. The SOA mass concentration during dark aging was 1.6 and 1.8 times that of the initial POA for beech and birch (Exp. 1A and 2A), respectively, whereas the average ratio was $1.9(1.6-2.6)$ for spruce (Table 3; see also Supplement Sect. S2).
Direct measurements of the hydroxyl free radical $(\mathrm{OH})$ concentrations are challenging; therefore, the $\mathrm{OH}$ concentration, the related $\mathrm{OH}$ exposure and the so-called atmospheric age in the smog chamber were ascertained by an indirect method based on the decay of butanol-d9 (Barmet et al., 2012). A comparison between lab studies and atmospheric measurements is easier when the age is estimated. In our experiments, the conditions in the chamber were indicative of polluted atmospheric boundary-layer conditions with an $\mathrm{OH}$ concentration of $(0.5-5) \times 10^{6}$ molec $\mathrm{cm}^{-3}$, ozone concentrations of 20-90 ppb and $\mathrm{NO}_{x}$ concentrations of 40-120 ppb (Fig. 2, Table 4; e.g., Atkinson, 2000; Lin et al., 2011). HONO was added in experiment $3 \mathrm{~B}$, leading to high oxidant and $\mathrm{NO}_{x}$ levels (Fig. 2b).

In experiments $1 \mathrm{~B}$ and $2 \mathrm{~B}$ (Fig. 2a), three distinct periods can be identified. First (Fig. 2a: A), logwood emissions were added to the chamber from the first batch ( $35 \mathrm{~min}$ ) and subsequently stabilized as identified by constant $\mathrm{CO}_{2}$ and $\mathrm{OA}$ concentrations. Second (Fig. 2a: B), ozone feeding after the stabilization initiated ozonolysis and $\mathrm{NO}_{3}$ radical reactions (e.g., Rollins et al., 2012), leading to the oxidation of VOCs and the formation of low-vapor-pressure reaction products that condensed onto existing soot agglomerates. This generated 1.6 and 1.8 times more SOA mass than the initial POA mass for the fast and slow ignition cases, respectively (Table 3). In the third period (Fig. 2a: C), starting when the UV lights were switched on, rapid growth in SOA was observed. It can be assumed that in this case, the aging reactions were mainly driven by $\mathrm{OH}$ radicals, whose aging times corresponded to $0.6-0.7$ days (Table 4 ) of equivalent atmospheric aging at typical boundary-layer $\mathrm{OH}$ concentrations of $1 \times 10^{6}$ molec $\mathrm{cm}^{-3}$. As a result, the total SOA mass increased to 1.9 (Exp. 1B) and 2.4 (Exp. 2B) times the initial POA mass.

Experiment $3 \mathrm{~B}$ was similar to $1 \mathrm{~B}$ and $2 \mathrm{~B}$ except that HONO (Fig. 2b: H) was added to the chamber. In addition, propene $(\sim 5.1 \mathrm{ppm})$ was injected into the chamber after the HONO injection to adjust the VOC-to- $\mathrm{NO}_{x}$ ratio to a value similar to those of the original emissions (the ratio after propene injection was 5.7). The products from propene oxidation do not contribute to SOA formation alone (Platt et 
Table 3. SOA (OA-POA) emissions ( $\mathrm{mg} \mathrm{kg}^{-1}$ fuel) and SOA-to-POA / OA-to-POA ratios for all of the experiments. Dark aging results are shown in bold.

\begin{tabular}{lccc|ccc}
\hline & \multicolumn{3}{c}{ Dark/UV aging } & \multicolumn{3}{c}{ Dark + UV aging } \\
\cline { 2 - 7 } Exp. & SOA & SOA / POA & OA / POA & SOA & SOA / POA & OA / POA \\
\hline $1 A^{\mathrm{a}}$ & $\mathbf{1 2 6}$ & $\mathbf{6 0} \%$ & $\mathbf{1 . 6}$ & - & - & - \\
$2 \mathrm{~A}^{\mathrm{a}}$ & $\mathbf{1 7 0}$ & $\mathbf{7 7} \%$ & $\mathbf{1 . 8}$ & - & - & - \\
$3 \mathrm{~A}^{\mathrm{a}}$ & $\mathbf{1 7 5}$ & $\mathbf{1 6 5} \%$ & $\mathbf{2 . 6}$ & - & - & - \\
$1 \mathrm{~B}$ & $\mathbf{1 0 0}$ & $\mathbf{6 3} \%$ & $\mathbf{1 . 6}$ & 137 & $87 \%$ & 1.9 \\
$2 \mathrm{~B}$ & $\mathbf{1 7 2}$ & $\mathbf{7 5} \%$ & $\mathbf{1 . 8}$ & 308 & $135 \%$ & 2.4 \\
$3 \mathrm{~B}$ & $\mathbf{1 0 1}$ & $\mathbf{6 8} \%$ & $\mathbf{1 . 7}$ & 173 & $116 \%$ & 2.2 \\
$4 \mathrm{~B}^{\mathrm{b}}$ & 91 & $77 \%$ & 1.8 & - & - & - \\
$5 \mathrm{~B}^{\mathrm{b}}$ & 237 & $115 \%$ & 2.1 & - & - & - \\
\hline
\end{tabular}

a Only dark aging. ${ }^{\text {b }}$ Only UV aging.

Table 4. Chemical ages (days) for the second set of chamber experiments (Exp. 1B-5B) and corresponding parameters: average OH concentration $\left(\right.$ molec $\left.\mathrm{cm}^{-3}\right)$ and $\mathrm{OH}$ exposure $\left(\operatorname{molec} \mathrm{cm}^{-3} \mathrm{~s}\right)$ based on the decay of butanol-d9 (Barmet et al., 2012). The equivalent chemical age was calculated assuming an average atmospheric $\mathrm{OH}$ concentration of $1.0 \times 10^{6}$ molecules $\mathrm{cm}^{-3}$.

\begin{tabular}{lccc|ccc}
\hline & \multicolumn{3}{c|}{ Dark aging } & \multicolumn{3}{c}{ UV aging } \\
\cline { 2 - 7 } Exp. & OH conc. & OH exp & Age & OH conc. & OH exp. & Age \\
\hline 1B & $<$ DL & $<$ DL & $<$ DL & $4.6 \mathrm{E}+6$ & $5.0 \mathrm{E}+10$ & 0.58 \\
2B & $6.6 \mathrm{E}+5$ & $9.2 \mathrm{E}+9$ & 0.11 & $4.9 \mathrm{E}+6$ & $5.2 \mathrm{E}+10$ & 0.59 \\
3B & $4.7 \mathrm{E}+5$ & $7.7 \mathrm{E}+9$ & 0.10 & $2.4 \mathrm{E}+6$ & $2.6 \mathrm{E}+10$ & 0.30 \\
4B & - & - & - & $3.4 \mathrm{E}+6$ & $5.1 \mathrm{E}+10$ & 0.58 \\
5B & - & - & - & $4.6 \mathrm{E}+6$ & $6.6 \mathrm{E}+10$ & 0.77 \\
\hline
\end{tabular}

al., 2013; Leskinen et al., 2014). The $\mathrm{SO}_{4}$ mass increased because a small amount (from 1.5 to $2.5 \mathrm{ppb}$ ) of $\mathrm{SO}_{2}$ ended up in the chamber together with the HONO addition. This secondary sulfate existed probably as sulfuric acid due to absence of base such as $\mathrm{NH}_{3}$. This was indicated by the very low ammonium ion concentrations. The overall SOA mass increased to 2.2 times the initial the POA mass (Table 3). However, the butanol-d9 decay indicated atmospheric aging equivalent to only 0.4 days (Table 4 ). This observation may be interpreted by the fact that although the photolysis of HONO acts as the source of OH radicals, the high concentration of propene and $\mathrm{NO}_{x}$ may have scavenged $\mathrm{OH}$ radicals, leading to a slower butanol-d9 decay rate than in the other experiments. The UV lights were turned on immediately after ozone injection in experiments $4 \mathrm{~B}$ and $5 \mathrm{~B}$ (Fig. 2c). After $4 \mathrm{~h}$ of photo-oxidation, the SOA mass increased by factors of 1.8 (Exp. 4B) and 2.1 (Exp. 5B) compared to the initial POA mass. This mass increase occurred quickly; most of the SOA was formed during the first hour of photo-oxidation. The mass increase due to photo-oxidation was 10 and $32 \mu \mathrm{g} \mathrm{h}^{-1}$ for fast and slow ignition cases, respectively. The corresponding first hour dark aging SOA formation rates were 8 and $12 \mu \mathrm{g} \mathrm{h}^{-1}$, respectively.

Substantial SOA formation was generally observed in every experiment performed with logwood combustion (birch, beech and spruce). As expected, the VOC-to- $\mathrm{NO}_{x}$ ratios affect SOA formation: combustion under higher VOC-to- $\mathrm{NO}_{x}$ ratios generates more SOA, showing that the burning conditions are likely a decisive factor in SOA formation. The results also show that photo-oxidation is faster than dark aging, which is expected. Furthermore, our findings emphasize the importance of dark aging, which appears to generate similar SOA mass loadings as UV aging.

\subsection{OA composition}

The elemental OA composition and atomic ratios were calculated from the high-resolution AMS spectra for each experiment to monitor dynamic changes in the OA composition during aging. The OA spectra of non-aged wood combustion emissions contained high amounts of oxygenated organic species with all wood species. The average carbon oxidation state $\overline{\mathrm{OS}}_{\mathrm{C}}$ of non-aged $\mathrm{OA}(\mathrm{POA})$, which can be estimated by using (Kroll et al., 2011; Canagaratna et al., 2015)

$\overline{\mathrm{OS}}_{\mathrm{C}} \approx 2 \times \mathrm{O}: \mathrm{C}-\mathrm{H}: \mathrm{C}$,

ranged from -0.4 to -0.8 with an average $\mathrm{O}: \mathrm{C}$ ratio of 0.5 and an $\mathrm{H}: \mathrm{C}$ ratio of 1.5 (Table 5). The POA oxidation state and OM-to-OC ratio of spruce emissions were higher than their equivalents for beech and birch POA. Higher oxidation 


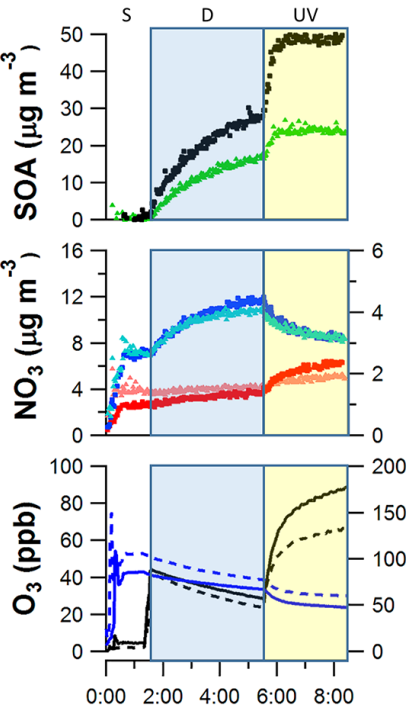

(a) Time from ignition (h)
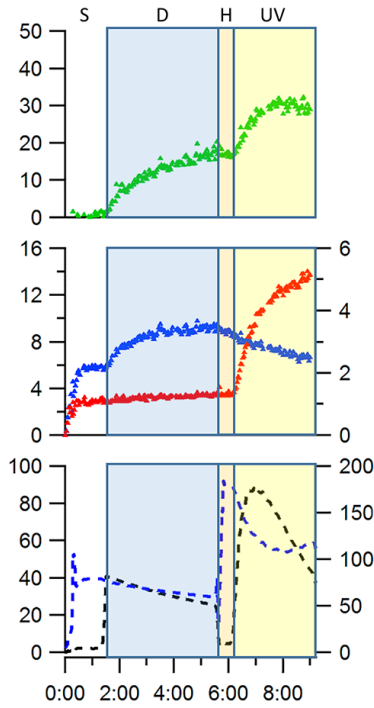

(b)

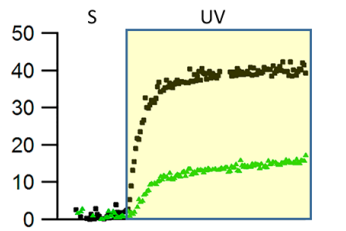

SOA (Slow ignition)

SOA (Fast ignition)
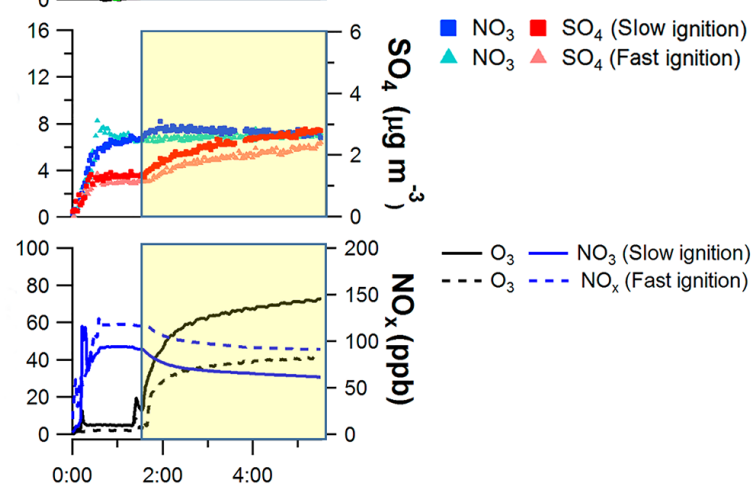

(c) Time from ignition $(h)$

Figure 2. SOA mass and selected trace gas concentrations in a smog chamber for experiments (a) $1 \mathrm{~B}$ and $2 \mathrm{~B}$, (b) 3B, and (c) 4B and 5B. Stabilization ( $40 \mathrm{~min}$ ) followed by filling the chamber $(35 \mathrm{~min}$ ) is marked as $\mathrm{S}$, dark aging as $\mathrm{D}, \mathrm{HONO}$ addition as $\mathrm{H}$ and $\mathrm{UV}$ aging as UV. $\mathrm{NO}_{x} / 5$ and $\mathrm{O}_{3} / 7$ after the $\mathrm{HONO}$ addition is shown in Fig $2 \mathrm{~b}$. The $\mathrm{SO}_{4}$ mass increase in Fig. $2 \mathrm{~b}$ was mainly an artefact caused by $\mathrm{SO}_{2}$ which ended up in the chamber together with the HONO addition.

Table 5. Overview of the OA elemental analysis at the end of each experimental stage (stabilization, dark aging and UV aging); dark aging results are shown in bold.

\begin{tabular}{|c|c|c|c|c|c|c|c|c|c|c|c|c|}
\hline \multirow[b]{2}{*}{ Exp. } & \multicolumn{8}{|c|}{ Dark/UV aging } & \multicolumn{4}{|c|}{ Total } \\
\hline & $\mathrm{O}: \mathrm{C}$ & $\mathrm{H}: \mathrm{C}$ & $\mathrm{OM}: \mathrm{OC}$ & OS & $\mathrm{O}: \mathrm{C}$ & $\mathrm{H}: \mathrm{C}$ & OM : OC & OS & $\mathrm{O}: \mathrm{C}$ & $\mathrm{H}: \mathrm{C}$ & $\mathrm{OM}: \mathrm{OC}$ & OS \\
\hline $1 \mathrm{~A}$ & 0.41 & 1.55 & 1.69 & -0.73 & 0.83 & 1.31 & 2.21 & 0.35 & - & - & - & - \\
\hline $2 \mathrm{~A}$ & 0.35 & 1.50 & 1.60 & -0.80 & 0.75 & 1.29 & 2.11 & 0.21 & - & - & - & - \\
\hline $3 \mathrm{~A}$ & 0.53 & 1.48 & 1.84 & -0.42 & 0.77 & 1.43 & 2.15 & 0.11 & - & - & - & - \\
\hline $1 \mathrm{~B}$ & 0.55 & 1.52 & 1.86 & -0.42 & 0.81 & 1.33 & 2.19 & 0.29 & 0.83 & 1.31 & 2.21 & 0.34 \\
\hline $2 \mathrm{~B}$ & 0.53 & 1.50 & 1.84 & -0.44 & 0.74 & 1.35 & 2.10 & 0.13 & 0.82 & 1.30 & 2.20 & 0.33 \\
\hline $3 B$ & 0.47 & 1.56 & 1.75 & -0.62 & 0.78 & 1.33 & 2.15 & 0.22 & 0.96 & 1.29 & 2.39 & 0.63 \\
\hline $4 \mathrm{~B}$ & 0.55 & 1.51 & 1.87 & -0.41 & 0.73 & 1.38 & 2.09 & 0.08 & - & - & - & - \\
\hline $5 B$ & 0.51 & 1.52 & 1.81 & -0.50 & 0.75 & 1.36 & 2.11 & 0.14 & - & - & - & - \\
\hline
\end{tabular}

states of POA from spruce emissions (Eq. 1) compared to beech and birch emissions can be explained by the softwood material. The organic composition of softwood emissions, such as spruce, is influenced by resin acids, such as pimaric, iso-pimaric, sandaracopimaric and abietic acids (Simoneit and Elias, 2001), that are not emitted from hardwoods such as beech and birch. In addition, the concentrations of aromatic VOCs (Fig. S2) were higher for spruce than for beech and birch. Because these compounds are important precursors of SOA, they are likely to affect the total SOA formation and its characteristics in the spruce combustion experiments.

The $\overline{\mathrm{OS}}_{\mathrm{C}}$ (Fig. 3) increased from approximately -0.5 (Table 5) to 0.1-0.3 during dark aging, which is a level of aged SOA that is produced by multiple oxidation reactions (Kroll et al., 2011). An $\overline{\mathrm{OS}}_{\mathrm{C}}$ level of -0.5 corresponds to an upper end of fresh biomass burning aerosol, underlining that $\log$ wood combustion generates a higher oxidation state OA than wildfire biomass burning. This can be associated with the fact that the emissions source of our study includes the low temperature ignition phase of the wood batch which is shown to emit relatively high amounts of oxidized organics, formed via pyrolytic decomposition of wood polymers (Czech et al., 2016). Moreover, the mass peaks associated with oxygenated OA (OOA), such as $\mathrm{CHO}^{+}, \mathrm{C}_{2} \mathrm{H}_{3} \mathrm{O}^{+}$and $\mathrm{CO}_{2}^{+}$, increased distinctly during the 4-hour dark aging period and in conjunction with nitrate-related peaks. The highly oxidized ions, i.e., $\mathrm{C}_{x} \mathrm{H}_{y} \mathrm{O}_{z>1}^{+}$(total of 391 ions), increased more than the ions with intermediate oxygen content (i.e., $\mathrm{C}_{x} \mathrm{H}_{y} \mathrm{O}^{+}$; total of 245 ions). Thus, relatively highly oxidized species, such 

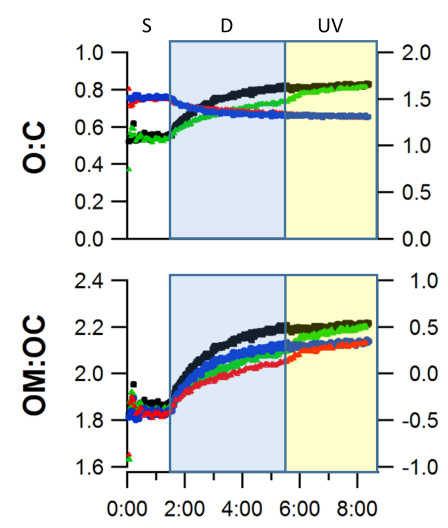

(a)
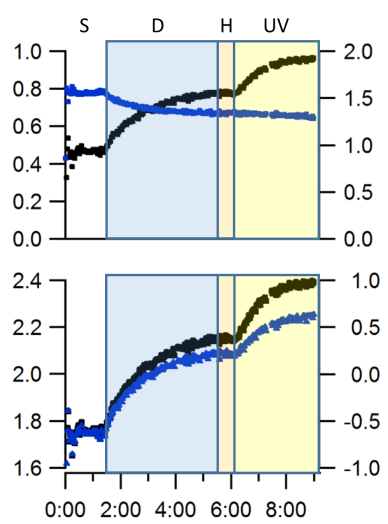

(b) Time from ignition (h)

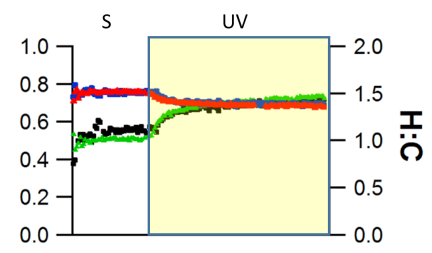

$\mathrm{O} C$ (Fast ignition)

- 0:C (Slow ignition)

- $\mathrm{H}: \mathrm{C}$ (Fast ignition)

- $\mathrm{H}: \mathrm{C}$ (Slow ignition)

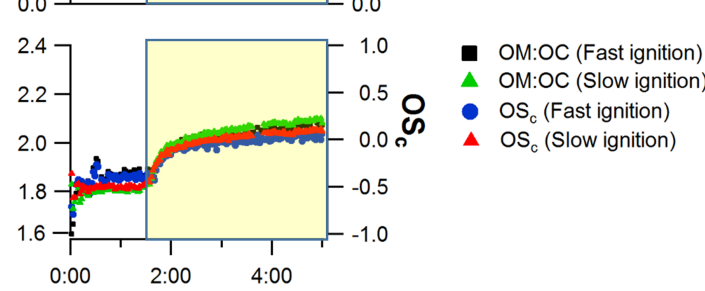

(c) Time from ignition (h)

Figure 3. Effect of aging on OA elemental composition for experiments (a) $1 \mathrm{~B}$ and $2 \mathrm{~B}$, (b) $3 \mathrm{~B}$ and (c) 4B and 5B. Stabilization is marked as $\mathrm{S}$, dark aging as D, HONO addition as $\mathrm{H}$ and UV aging as UV.

as carboxylic acids or peroxides, dominated the observed increase in the $\mathrm{O}: \mathrm{C}$ ratio and the oxidation state $\overline{\mathrm{OS}}_{\mathrm{C}}$.

The enhancement in OA oxidation occurred more rapidly during the first $2 \mathrm{~h}$ of dark aging and slowed during the second half of the dark aging period (Fig. 3). Switching on the UV lights after the dark aging period only slightly increased the $\overline{\mathrm{OS}}_{\mathrm{C}}$, although it caused a substantial and rapid SOA mass increase (Figs. 2a and 3a). In contrast, in experiment 3B, oxidation was further accelerated by the injection of HONO immediately before UV light exposure, leading to an $\overline{\mathrm{OS}}_{\mathrm{C}}$ peak value of 0.6 (Fig. 3b), which corresponds to highly oxidized ambient OA. When the UV lights were switched on directly after the sample stabilization period (Exp. 4B and 5B), OA oxidation was found to occur quickly (Fig. 3c), although the oxidation state remained at a lower level (from 0 to 0.1 ) than during the dark aging experiments.

The effect of $\mathrm{OH}$ exposure on OA is summarized in Fig. 4, emphasizing the strong effect of dark aging on the OA composition when the oxidation state increased strongly without UV aging. Fast ignition (Exp. 1B and 4B) generated more oxidized OA than slow ignition (Exp. 2B and 5B), although these differences decreased when the SOA mass fraction increased. An intermediate slope of -1 in van Krevelen diagrams (Heald et al., 2010; Fig. 4c) corresponds to an addition of carboxylic acid groups without fragmentation, which would increase the slope toward -0.5 ( $\mathrm{Ng}$ et al., 2011). Figure 4 depicts van Krevelen slope values of -0.64 to -0.67 for the experiments; these slopes were found to be slightly steeper for the fast ignition experiments $1 \mathrm{~B}$ and $4 \mathrm{~B}$ than for the dark aging experiments $2 \mathrm{~B}$ and $5 \mathrm{~B}$. These slope values range in van Krevelen space over a region where ambient OA components appear (Ortega et al., 2016). The OA aging was found to follow a similar trend with ambient observations ( $\mathrm{Ng}$ et al., 2011), showing that our chamber experiments simulate polluted boundary-layer conditions. The effect of HONO injection on the OA composition can be ob-
Table 6. Elemental composition of the PMF factors POA1, POA2, SOA1, SOA2 and SOA3.

\begin{tabular}{lcccr}
\hline Factor & $\mathrm{O}: \mathrm{C}$ & $\mathrm{H}: \mathrm{C}$ & $\mathrm{OM}: \mathrm{OC}$ & $\mathrm{OS}$ \\
\hline POA1 & 0.46 & 1.58 & 1.74 & -0.67 \\
POA2 & 0.45 & 1.58 & 1.74 & -0.69 \\
SOA1 & 0.60 & 1.40 & 1.92 & -0.20 \\
SOA2 & 0.86 & 1.26 & 2.26 & 0.47 \\
SOA3 & 0.95 & 1.28 & 2.38 & 0.62 \\
\hline
\end{tabular}

served as a van Krevelen slope increase. This change in the slope can be explained by the replacement of a hydrogen with an alcohol group $(-\mathrm{OH})$.

\subsection{SOA composition}

\subsubsection{PMF analyses of the second set of experiments}

To investigate the OA composition in the detail, PMF was used to separate SOA, POA and their subgroups from the total OA. The method of analyzing AMS data with PMF is described in Lanz et al. (2007) and Ulbrich et al. (2009). In addition to $\mathrm{OA}$ spectra, inorganic $\mathrm{NO}$ and $\mathrm{NO}_{2}$ spectra were added to the PMF to investigate particulate organic nitrate formation following Hao et al. (2014) and Kortelainen et al. (2016). To date, most AMS-PMF analyses have been performed with ambient measurements (e.g., Zhang et al., 2011), although laboratory-based AMS datasets have been successfully analyzed using this method in recent years (e.g., Kortelainen et al., 2015; Corbin et al., 2015b).

PMF was conducted with a five-factor solution. Solutions with more factors do not increase the physical realistic meaning; for example, no correlation with tracers can be identified. Thus, a five-factor solution was chosen for further investigation (Supplement Sects. S3 and S4). The factor identification was confirmed by comparing the time se- 

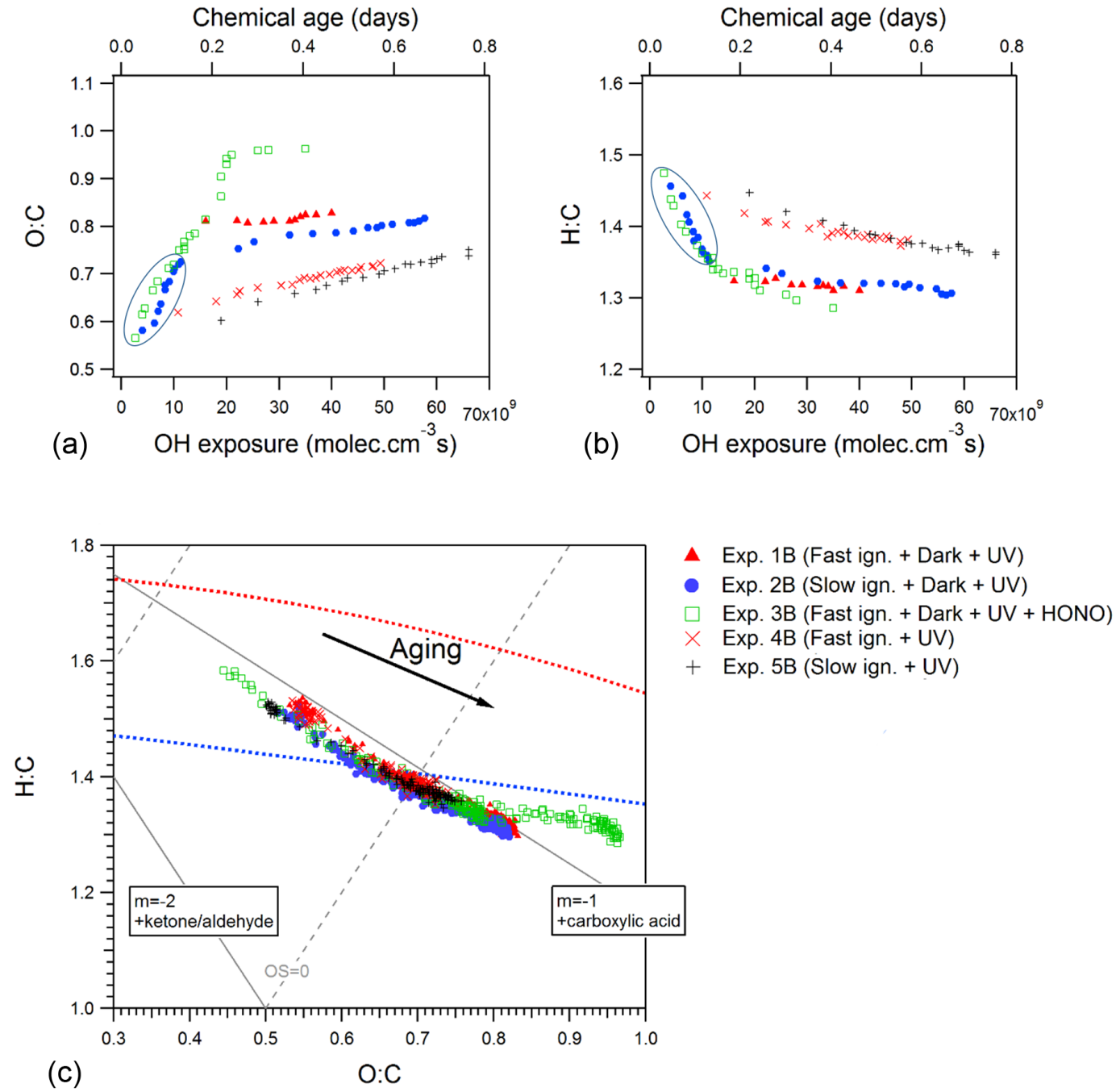

Figure 4. Comparison of OA elemental composition for the second set of experiments (Exp. 1B-5B): OA elemental composition vs. OH exposure (a-b) and van Krevelen diagram (c). The improved-ambient method from Canagaratna et al. (2015) was applied for the elemental analysis. The dotted lines define the triangular space where ambient OA components are typically located (Ng et al., 2010) and dark aging periods are circled in grey $(\mathbf{a}-\mathbf{b})$.

ries and mass spectra of each factor with external particulate tracers $\left(\mathrm{NO}_{3}^{-}, \mathrm{SO}_{4}^{2-}, \mathrm{NH}_{4}^{+}, \mathrm{Cl}^{-}, \mathrm{PAH}, \mathrm{C}_{2} \mathrm{H}_{3} \mathrm{O}^{+}\right.$and $\mathrm{C}_{4} \mathrm{H}_{9}^{+}$), available gas-phase measurements $\left(\mathrm{NO}, \mathrm{NO}_{2}, \mathrm{NO}_{x}\right.$, $\mathrm{SO}_{2}$ and $\mathrm{O}_{3}$; Fig. S6), reference source mass spectra available from the AMS MS database (High-Resolution AMS Spectral Database, http://cires.colorado.edu/jimenez-group/ HRAMSsd/; Ulbrich et al., 2009) and wood combustion mass spectra from Kortelainen et al. 2015 and Aiken et al. 2009 (Table S2). The following factors were identified: POA1, POA2, SOA1, SOA2 and SOA3 (Table 6).

\subsubsection{Interpretation of the PMF results}

Figure 5 illustrates the evolution of the OA composition based on the PMF analysis. The aging processes of OA in- clude functionalization reactions (the addition of oxygencontaining functional groups), which continuously decrease the volatility of organic compounds, and fragmentation reactions (the breaking of carbon-carbon bonds), which simultaneously result in higher-volatility products (Kroll et al., 2011; Lambe et al., 2012). Oligomerization, polymerization and heterogeneous oxidation typically appear on longer timescales; thus, we do not expect these mechanisms to significantly affect SOA aging when chemical aging times are relatively short, i.e., less than $24 \mathrm{~h}$.

PMF differentiates three SOA factors, SOA1, SOA2 and SOA3 (Figs. 5 and S6), representing the three major oxidizers: ozone, the $\mathrm{OH}$ radical and the nitrate radical (e.g., Kroll and Seinfeld 2008; Chacon-Madrid and Donahue 2011; Rollins et al., 2012). During dark aging, when the OH con- 

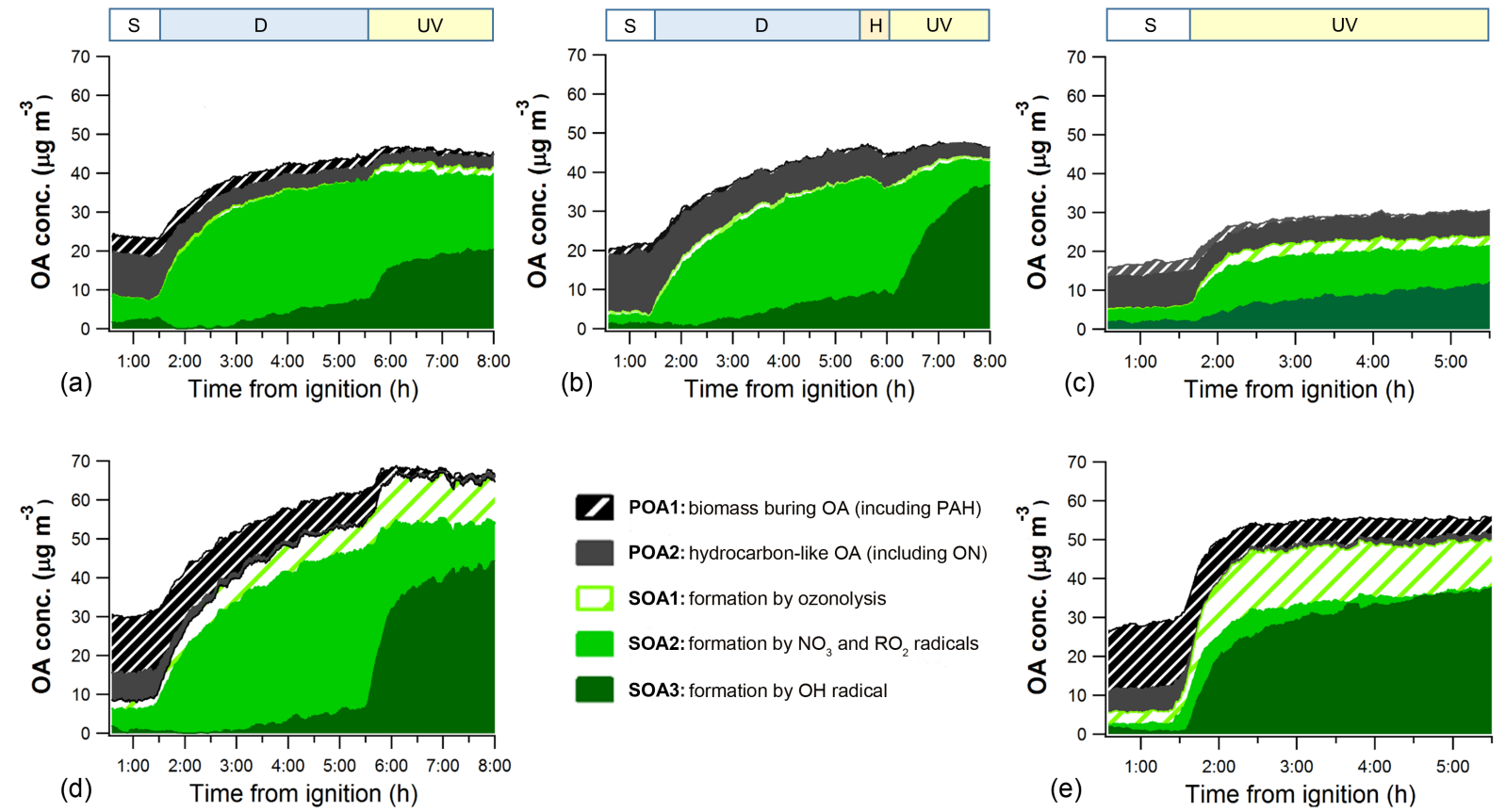

Figure 5. Evolution of OA during aging based on PMF calculations: (a) Exp. 1B (fast ignition), (b) Exp. 3B (fast ignition), (c) Exp. 4B (fast ignition), (d) Exp. 2B (slow ignition) and (e) Exp. 5B (slow ignition). The stabilization phase is marked as S, dark aging as D, the HONO addition as $\mathrm{H}$ and $\mathrm{UV}$ aging as $\mathrm{UV}$ in the upper panel.

centrations were low, ozonolysis and nitrate radicals dominated the oxidation processes of VOCs and subsequent formation of SOA. In contrast, when the UV lights were switched on, $\mathrm{OH}$ radicals dominated the aging process. The species in the first SOA factor (SOA1) are expected to be formed via ozonolysis of unsaturated compounds, e.g., alkenes, dienes, terpenes, because other major compound classes are not sufficiently reactive with ozone. This can be seen in the SOA1 factor, which was higher in the slow ignition case with higher alkene fractions than in the fast ignition case (Fig. S2) when SOA1 was only less than $\sim 10 \%$ of the total SOA. The oxidation level of SOA1 was clearly lower than SOA2 and SOA3 (Table 6), suggesting that the oxidation products of ozonolysis from logwood combustion are less oxidized than the oxidation products of $\mathrm{NO}_{3}$ or $\mathrm{OH}$ radicals, which agrees with earlier findings (e.g., Chhabra et al., 2010).

The species in the second SOA factor (SOA2) are most likely present as secondary ONs, which is indicated by the following observations. First, the SOA2 factor exhibited a similar time series to that of particulate $\mathrm{NO}_{3}$ (Figs. S6 and S7), and there was a lack of base, such as $\mathrm{NH}_{3}$, to form inorganic nitrate. Second, SOA2 increased considerably during dark aging and declined during UV-induced aging (Fig. 5a, b and d). This agrees with the earlier findings on organonitrate formation in ambient air (Rollins et al., 2012; Fry et al., 2013; Kortelainen et al., 2016; Kiender-Scharr et al., 2016) and with the high NO-to- $\mathrm{NO}_{2}$ ratio of the SOA2 factor. Third, the mass spectrum of SOA2 has NO-to- $\mathrm{NO}_{2}$ ion signal ratio of 7.8 , which is distinctly higher than the corresponding ratio of 2.5 in the standard ammonium nitrate calibration. Such a NO-to- $\mathrm{NO}_{2}$ ratio indicates the presence of organonitrates (Farmer et al., 2010; Kiendler-Scharr et al., 2016). This result is further indicated by the particle size distributions for $\mathrm{NO}_{3}$ and OA being identical. The SOA2 concentration increased quickly during the first hour of dark aging and reached a plateau before the UV aging period. SOA2 decreased after the UV lights were switched on to a similar or slightly higher level than during the stabilization phase. This result can be explained by the decomposition of organonitrates under UV irradiation (e.g., Nguyen et al., 2015; Kortelainen et al., 2016).

The formation of secondary organic nitrate factor occur via two channels: one is through the $\mathrm{NO}_{3}$ radical oxidation in case of excessive $\mathrm{NO}_{x}$ and $\mathrm{O}_{3}$ in the dark aging experiments (as described in previous chapter) and the another channel is through photochemistry via reactions of peroxy radical $\left(\mathrm{RO}_{2}\right)$ with $\mathrm{NO}$ (Atkinson et al., 2000). This most likely explains why we are seeing the formation of SOA2 also after UV lights were switched on in presence of high NO in the experiment 4B (Fig. 5c).

The third SOA factor (SOA3) was primarily formed after the UV lights were switched on; it represents SOA formation dominated by the $\mathrm{OH}$ radical. SOA3 exhibited the highest oxidation state, 0.6 (Table 6), among the identified SOA factors, comparable to a level of highly oxidized ambient OA 


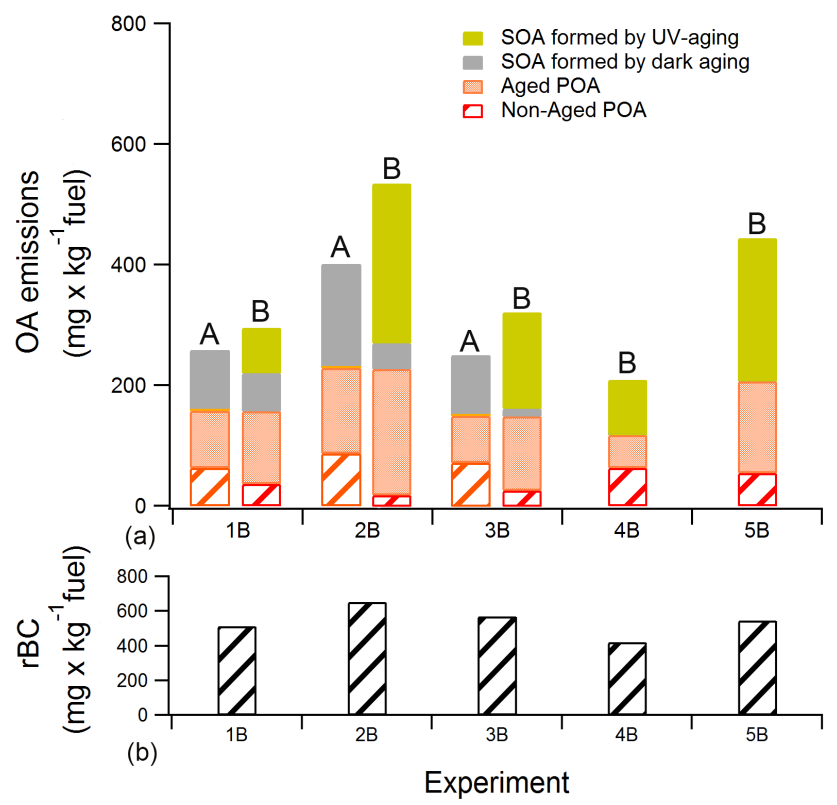

Figure 6. Aged and non-aged POA emission together with SOA at the end of dark (a) and UV aging (b) periods based on PMF calculations (Exp. 1B-5B) as well as (b) refractory black carbon (rBC) emissions.

(Kroll et al., 2011). The potential precursors for this factor are likely aromatic compounds, which have typically slow reaction rates in the presence of ozone. These may include, for example, toluene, naphthalene, benzene and benzaldehyde, which were recently identified as some of the major SOA precursor for a wood stove (Bruns et al., 2016). This conclusion is in agreement with the clearly higher SOA3 mass in the slow ignition case, which contained higher amounts of aromatic compounds in the primary emissions, than in the fast ignition case (Fig. S2). After UV aging, SOA3 represented about half of the total SOA mass for fast ignition (Exp. 1B and $4 \mathrm{~B}$ ) and $70 \%$ for slow ignition (Exp. 2B and 5B). The PMF results also revealed that after HONO addition and subsequent UV aging, the SOA3 factor represented $94 \%$ of the SOA mass. Small fractions of SOA3 appeared during dark aging, which is a potential indication of $\mathrm{OH}$ production by ozone without UV lights when a Criegee is falling apart (Table 4, Seinfeld and Pandis, 2006).

Primary organic aerosol factor, POA1 (biomass burning organic aerosol factor including $\mathrm{PAH}$ ), was higher during the slow ignition cases than the fast ignition experiments opposite to POA2 (HOA factor including high $\mathrm{NO}$ and $\mathrm{NO}_{2}$ peaks). The PAH compounds (Dzepina et al., 2007) included in the POA1 were observed in low concentrations. Total PAH concentration ranged from 0.1 to $0.5 \mu \mathrm{g} \mathrm{m}^{-3}$ (Fig. S6), which is about $1 \%$ of total OA. POA factors were found to oxidize after the ozone addition, forming aged POA (Hennigan et al., 2011), which can be defined as the concentration of the initial POA minus the residual POA, based on the PMF calcula-
Table 7. Organonitrate $(\mathrm{ON})$ emissions $\left(\mathrm{mg} \mathrm{kg}^{-1}\right.$ fuel) from $\log$ wood combustion at the end of experimental periods (stabilization and dark aging) calculated using Eqs. (2) and (3) and corresponding NO-to- $\mathrm{NO}_{2}$ ratios.

\begin{tabular}{lcc|ccc}
\hline & \multicolumn{2}{c|}{ Stabilization } & \multicolumn{3}{c}{ Dark aging } \\
\cline { 2 - 5 } Exp. & $\mathrm{NO} / \mathrm{NO}_{2}$ & Emission & $\mathrm{NO} / \mathrm{NO}_{2}$ & Emission & Total \\
\hline 1A & 5.6 & 31.2 & 5.9 & 24.6 & 55.8 \\
2A & 5.3 & 27.4 & 8.3 & 47.7 & 75.1 \\
3A & 10.0 & 22.5 & 10.0 & 28.5 & 51.0 \\
1B & 6.9 & 34.9 & 7.9 & 21.5 & 56.4 \\
2B & 5.1 & 26.7 & 5.8 & 24.3 & 51.0 \\
3B & 5.4 & 22.7 & 6.5 & 25.7 & 48.4 \\
4B & 5.5 & 29.3 & - & - & 29.3 \\
5B & 4.5 & 19.8 & - & - & 19.8 \\
\hline
\end{tabular}

tions, at the end of the experiment (Figs. 5 and 6). The nonaged POA mass fraction (Exp. 1B-3B) was approximately $40-50 \%$ after dark aging and decreased to $8-23 \%$ after UV aging. UV aging experiments $4 \mathrm{~B}$ and $5 \mathrm{~B}$ without dark aging showed higher non-aged POA fractions of 54 and $27 \%$ for fast and slow ignition, respectively. These results are quite similar to Hennigan et al. (2011) for the photo-oxidation of open biomass burning experiments. They concluded that unreacted POA contributed $17 \%$ of the campaign-averaged OA mass, and heterogeneous reactions with $\mathrm{OH}$ could account for less than half of this POA transformation. The transformation of semi-volatile OA to low-volatile OA can involve both gas-phase oxidation followed by partitioning to the particle phase as well as heterogeneous reactions. Recent studies have shown that the reaction of $\mathrm{OH}$ or $\mathrm{O}_{3}$ radicals with the SOA coating is a potential oxidation path (Browne et al., 2015). Liu et al. (2012) showed that heterogeneous oxidation of PAHs driven by $\mathrm{NO}_{3}$ radicals can be faster than their corresponding gas-phase reactions when $\mathrm{OH}$ radical concentrations are low, i.e., during dark aging.

\subsubsection{Organonitrates}

ON mass can be calculated from (Farmer et al., 2010; Fry et al., 2013; Kiendler-Scharr et al., 2016)

$$
\begin{aligned}
\mathrm{OrgNO}_{3_{\text {frac }}} & =\frac{\left(1+R_{\mathrm{OrgNO}_{3}}\right) \times\left(R_{\text {measured }}-R_{\text {calib }}\right)}{\left(1+R_{\text {measured }}\right) \times\left(R_{\mathrm{OrgNO}_{3}}-R_{\text {calib }}\right)}, \\
\mathrm{OrgNO}_{3_{\text {mass }}} & =\mathrm{OrgNO}_{3_{\text {frac }}} \times \mathrm{NO}_{3},
\end{aligned}
$$

where $R_{\text {measured }}$ is the measured intensity ratio of $\mathrm{NO}_{2}$ and $\mathrm{NO}$ ions as a function of time in the individual datasets, $R_{\text {calib }}$ is the ratio observed in the $\mathrm{NH}_{4} \mathrm{NO}_{3}$ calibrations ( 0.6 for Exp. $1 \mathrm{~A}-3 \mathrm{~A}$ and 0.4 for Exp. $1 \mathrm{~B}-5 \mathrm{~B}$ ), and $R_{\mathrm{OrgNO}}$ is set to 0.1 (Kiendler-Scharr et al., 2016). This expression only applies if $\mathrm{NH}_{4} \mathrm{NO}_{3}$ is the only important inorganic nitrate addition to $\mathrm{ON}$ in the submicron mode because other nitrate salts have different fragmentation ratios (Farmer et al., 2010; Fry et al., 2013). However, alkali metals emitted from wood 
combustion, as mentioned in Section 3.1, appear mainly in the form of $\mathrm{A}_{2} \mathrm{SO}_{4}, \mathrm{ACl}$ and $\mathrm{A}_{2} \mathrm{CO}_{3}(\mathrm{~A}=\mathrm{K}$ or $\mathrm{Na}$; Sippula et al., 2007). Furthermore, $\mathrm{K}$ and $\mathrm{Na}$ as well as $\mathrm{CO}_{3}$ typically have relatively low concentrations in logwood combustion primary emissions (Nuutinen et al., 2014), which are clearly below the concentrations of nitrate in this study. Thus, it is impossible that alkali metal ions contributed significantly to the submicron $\mathrm{ON}$ during our experiments.

The mass spectra of OA (Fig. S6) suggested that, in addition to SOA2, high $\mathrm{NO}$ and $\mathrm{NO}_{2}$ ion signals in PMF mass spectrum were also present in POA2 factor with NO-to- $\mathrm{NO}_{2}$ ion signal ratio of 6.2. The total ON mass was calculated using Eqs. (2) and (3) with corresponding emissions of 20$75 \mathrm{mg} \mathrm{kg}^{-1}$ fuel (Table 7). Nitrate radical reactions and other mechanisms, such as termination reactions or $\mathrm{RO}_{2}$ with $\mathrm{NO}$ to ROONO and rearrangement to $\mathrm{RONO}_{2}$, could be the production mechanism of organonitrates.

\section{Conclusions}

Real-time measurements of OA aging and SOA formation from logwood combustion were conducted in a $29 \mathrm{~m}^{3} \mathrm{smog}$ chamber under dark (i.e., $\mathrm{O}_{3}$ and $\mathrm{NO}_{3}$ ) and UV (i.e., $\mathrm{OH}$ ) oxidation environments. The results represent modern masonry heater emissions used in northern Europe. Substantial SOA formation was observed in all dark and UV aging experiments, leading to nearly twice the initial OA mass. Higher SOA mass was observed for slow ignition (VOC to $\mathrm{NO}_{X}$ ratio $=5$ ) than for fast ignition ( $\mathrm{VOC}$ to $\mathrm{NO}_{X}$ ratio $=3$ ), which emphasizes the importance of the burning conditions for the aging processes.

A high fraction of $\mathrm{ON}$ was emitted from the combustion of all wood species, whereas secondary ON was mainly formed during dark aging. Secondary ON was formed from the oxidation of VOCs by $\mathrm{NO}_{3}$ radicals under nocturnal conditions and in the presence of ozone. These results imply that wood combustion is a significant source of $\mathrm{ON}$ to the atmospheric boundary layer.

Most of the POA was found to become oxidized after the ozone addition, forming aged POA, such that the remaining non-aged POA represented less than $25 \%$ of the total POA after $7 \mathrm{~h}$ of aging. It is likely that the aging process induces changes in the semi-volatile organic compounds in the POA such as PAH and oxy-PAH, which can impact the toxicity. The observed transformation of POA should be further evaluated and included in emission inventories and global model calculations.

The results obtained from this investigation provide new insights into SOA formation and transformation processes in polluted atmospheric conditions (plumes). These are prevalent, e.g., in the commonly observed haze pollution events, the features of which are very different from those reported for non-polluted aerosol systems in the atmosphere. Furthermore, the SOA formation from dark aging and aging by pho- tochemical reactions was connected for the first time to examine the fate of SOA from nighttime exposed to UV light. The results generally prove that logwood burning emissions are subject to intensive chemical processing in the atmosphere, with timescales of the order of hours, including dark periods.

\section{Data availability}

The data from this paper can be obtained by contacting the authors of this article.

\section{The Supplement related to this article is available online at doi:10.5194/acp-16-13251-2016-supplement.}

Acknowledgements. Financial support by the Academy of Finland (grant 258315), HICE Helmholtz Virtual Institute, the strategic funding of the University of Eastern Finland for the project on sustainable bioenergy, climate change and health, the DACH project WOOSHI and the Maj and Tor Nessling Foundation (201600029) are acknowledged.

Edited by: D. Topping

Reviewed by: two anonymous referees

\section{References}

Aiken, A. C., DeCarlo, P. F., and Jimenez, J. L.: Elemental analysis of organic species with electron ionization highresolution mass spectrometry, Anal. Chem., 79, 8350-8358, doi:10.21/ac071150w, 2007.

Akagi, S. K., Craven, J. S., Taylor, J. W., McMeeking, G. R., Yokelson, R. J., Burling, I. R., Urbanski, S. P., Wold, C. E., Seinfeld, J. H., Coe, H., Alvarado, M. J., and Weise, D. R.: Evolution of trace gases and particles emitted by a chaparral fire in California, Atmos. Chem. Phys., 12, 1397-1421, doi:10.5194/acp-12-13972012, 2012.

Allan, J., Jimenez, J., Williams, P., Alfarra, M., Bower, K., Jayne, J., Coe, H., and Worsnop, D.: Quantitative sampling using an Aerodyne aerosol mass spectrometer 1. Techniques of data interpretation and error analysis, J. Geophys. Res., 108, 4090, doi:10.1029/2002JD002358, 2003.

Atkinson, R.: Atmospheric chemistry of VOCs and $\mathrm{NO}_{x}$, Atmos. Environ., 34, 2063-2101, 2000.

Barmet, P., Dommen, J., DeCarlo, P. F., Tritscher, T., Praplan, A. P., Platt, S. M., Prévôt, A. S. H., Donahue, N. M., and Baltensperger, U.: $\mathrm{OH}$ clock determination by proton transfer reaction mass spectrometry at an environmental chamber, Atmos. Meas. Tech., 5, 647-656, doi:10.5194/amt-5-647-2012, 2012.

Bond, T. C., Streets, D. G., Yarber, K. F., Nelson, S. M., Woo, J. H., and Klimont, Z.: A technology-based global inventory of black and organic carbon emissions from combustion, J. Geophys. Res.-Atmos., 109, D14203, doi:10.1029/2003JD003697,2004. 
Browne, E., Franklin, J., Canagaratna, M., Massoli, P., Kirchstetter, T., Worsnop, D., Wilson, K., and Kroll, J.: Changes to the chemical composition of soot from heterogeneous oxidation reactions, J. Phys. Chem. A, 119, 1154-1163, doi:10.1021/jp511507d, 2015.

Bruns, E. A., Krapf, M., Orasche, J., Huang, Y., Zimmermann, R., Drinovec, L., Mocnik, G., El-Haddad, I., Slowik, J. G., Dommen, J., Baltensperger, U., and Prévôt, A. S. H.: Characterization of primary and secondary wood combustion products generated under different burner loads, Atmos. Chem. Phys., 15, 2825-2841, doi:10.5194/acp-15-2825-2015, 2015.

Bruns, E. A., El Haddad, I., Slowik, J. G., Kilic, D., Klein, F., Baltensperger, U., and Prevot, A. S. H.: Identification of significant precursor gases of secondary organic aerosols from residential wood combustion, Sci. Rep., 6, 27881, doi:10.1038/srep27881, 2016.

Butt, E. W., Rap, A., Schmidt, A., Scott, C. E., Pringle, K. J., Reddington, C. L., Richards, N. A. D., Woodhouse, M. T., RamirezVillegas, J., Yang, H., Vakkari, V., Stone, E. A., Rupakheti, M., S. Praveen, P., G. van Zyl, P., P. Beukes, J., Josipovic, M., Mitchell, E. J. S., Sallu, S. M., Forster, P. M., and Spracklen, D. V.: The impact of residential combustion emissions on atmospheric aerosol, human health, and climate, Atmos. Chem. Phys., 16, 873-905, doi:10.5194/acp-16-873-2016, 2016.

Canagaratna, M. R., Jayne, J., Jimenez, J., Allan, J., Alfarra, M., Zhang, Q., Onasch, T., Drewnick, F., Coe, H., Middlebrook, A., Delia, A., Williams, L., Trimborn, A., Northway, M., DeCarlo, P., Kolb, C., Davidovits, P., and Worsnop, D.: Chemical and microphysical characterization of ambient aerosols with the Aerodyne aerosol mass spectrometer, Mass Spectrom. Rev., 26, 185-222, 2007.

Canagaratna, M. R., Jimenez, J. L., Kroll, J. H., Chen, Q., Kessler, S. H., Massoli, P., Hildebrandt Ruiz, L., Fortner, E., Williams, L. R., Wilson, K. R., Surratt, J. D., Donahue, N. M., Jayne, J. T., and Worsnop, D. R.: Elemental ratio measurements of organic compounds using aerosol mass spectrometry: characterization, improved calibration, and implications, Atmos. Chem. Phys., 15, 253-272, doi:10.5194/acp-15-253-2015, 2015.

Capes, G., Johnson, B., McFiggans, G., Williams, P. I., Haywood, J., and Coe, H.: Aging of biomass burning aerosols over West Africa: Aircraft measurements of chemical composition, microphysical properties, and emission ratios, J. Geophys. Res., 113, D00C15, doi:10.1029/2008JD009845, 2008.

Cappa, C., Onasch, T., Massoli, P., Worsnop, D., Bates, T., Cross, E., Davidovits, P., Hakala, J, Hayden, K., Jobson, T., Kolesar, K., Lack, D., Lerner, B., Li, S.-M., Mellon, D., Nuaaman, I., Olfert, J., Petäjä, T., Quinn, P., Song, C., Subramanian, R., Williams, E., and Zaveri, R.: Radiative absorption enhancements due to the mixing state of atmospheric black carbon, Science, 337, 10781081, doi:10.1126/science.1223447, 2012.

Chhabra, P. S., Flagan, R. C., and Seinfeld, J. H.: Elemental analysis of chamber organic aerosol using an aerodyne high-resolution aerosol mass spectrometer, Atmos. Chem. Phys., 10, 4111-4131, doi:10.5194/acp-10-4111-2010, 2010.

Chacon-Madrid, H. J. and Donahue, N. M.: Fragmentation vs. functionalization: chemical aging and organic aerosol formation, Atmos. Chem. Phys., 11, 10553-10563, doi:10.5194/acp11-10553-2011, 2011.
Corbin, J. C., Sierau, B., Gysel, M., Laborde, M., Keller, A., Kim, J., Petzold, A., Onasch, T. B., Lohmann, U., and Mensah, A. A.: Mass spectrometry of refractory black carbon particles from six sources: carbon-cluster and oxygenated ions, Atmos. Chem. Phys., 14, 2591-2603, doi:10.5194/acp-14-2591-2014, 2014.

Corbin, J. C., Keller, A., Lohmann, U., Burtcher, H., Sierau, B., and Mensah, A.: Organic emissions from a wood stove and a pellet stove before and after simulated atmospheric aging, Aerosol Sci. Technol., 49, 1037-1050, doi:10.1080/02786826.2015.1079586, 2015a.

Corbin, J. C., Lohmann, U., Sierau, B., Keller, A., Burtscher, H., and Mensah, A. A.: Black carbon surface oxidation and organic composition of beech-wood soot aerosols, Atmos. Chem. Phys., 15, 11885-11907, doi:10.5194/acp-15-11885-2015, 2015b.

Corbin, J. C., Othman, A., Allan, J. D., Worsnop, D. R.,Haskins, J. D., Sierau, B., Lohmann, U., and Mensah, A.: Peak-fitting and integration imprecision in the Aerodyne aerosol mass spectrometer: effects of mass accuracy on location-constrained fits, Atmos. Meas. Tech., 8, 4615-4636, doi:10.5194/amt-8-4615-2015, 2015c.

Crippa, M., Canonaco, F., Lanz, V. A., Äijälä, M., Allan, J. D., Carbone, S., Capes, G., Ceburnis, D., Dall'Osto, M., Day, D. A., DeCarlo, P. F., Ehn, M., Eriksson, A., Freney, E., Hildebrandt Ruiz, L., Hillamo, R., Jimenez, J. L., Junninen, H., Kiendler-Scharr, A., Kortelainen, A.-M., Kulmala, M., Laaksonen, A., Mensah, A. A., Mohr, C., Nemitz, E., O’Dowd, C., Ovadnevaite, J., Pandis, S. N., Petäjä, T., Poulain, L., Saarikoski, S., Sellegri, K., Swietlicki, E., Tiitta, P., Worsnop, D. R., Baltensperger, U., and Prévôt, A. S. H.: Organic aerosol components derived from 25 AMS data sets across Europe using a consistent ME-2 based source apportionment approach, Atmos. Chem. Phys., 14, 61596176, doi:10.5194/acp-14-6159-2014, 2014.

Czech, H., Sippula, O., Kortelainen, M., Tissari, J., Radischat, C., Passig, J., Streibel, T., Jokiniemi, J., and Zimmermann, R.: On-line analysis of organic emissions from residential wood combustion with single-photon ionization time-offlight mass spectrometry (SPI-TOFMS), Fuel, 177, 344-432, doi:10.1016/j.fuel.2016.03.036, 2016.

DeCarlo, P., Kimmel, J., Trimborn, A., Northway, M., Jayne, J., Aiken, A., Gonin, M., Fuhrer, K., Horvath, T., Docherty, K., Worsnop, D., and Jimenez J.: A field-deployable high-resolution time-of-flight aerosol mass spectrometer, Anal. Chem., 78, 8281-8289, doi:10.1021/ac061249n, 2006.

Denier van der Gon, H. A. C., Bergström, R., Fountoukis, C., Johansson, C., Pandis, S. N., Simpson, D., and Visschedijk, A. J. H.: Particulate emissions from residential wood combustion in Europe - revised estimates and an evaluation, Atmos. Chem. Phys., 15, 6503-6519, doi:10.5194/acp-15-6503-2015, 2015.

Donahue, N. M., Robinson, A. L., Stanier, C. O., and Pandis, S. N.: Coupled partitioning, dilution, and chemical aging of semivolatile organics, Environ. Sci. Technol., 40, 2635-2643, doi:10.1021/es052297c, 2006.

Drewnick, F., Hings, S., Curtius, J., Eerdekens, G., and Williams, J.: Measurement of fine particulate and gas-phase species during the New Year's fireworks 2005 in Mainz, Germany, Atmos. Environ., 40, 4316-4327, doi:10.1016/j.atmosenv.2006.03.040, 2006.

Dzepina, K., Arey, J., Marr, L. C., Worsnop, D. R., Salcedo, D., Zhang, Q., Onasch, T. B, Molina, L. T., Molina, M. J., and Jimenez, J. L.: Detection of particle-phase poly- 
cyclic aromatic hydrocarbons in Mexico City using an aerosol mass spectrometer, Int. J. Mass Spectrom., 263, 152-170, doi:10.1016/j.ijms.2007.01.010, 2007.

Elsasser, M., Busch, C., Orasche, J., Schön, C., Hartmann, H., Schnelle-Kreis, J., and Zimmerman, R.: Dynamic changes of the aerosol composition and concentration during different burning phases of wood combustion, Energ. Fuel, 27, 4959-4968, doi:10.1021/ef400684f, 2013.

Eriksson, A. C., Nordin, E. Z., Nyström, E. Z., Pettersson, E., Swietlicki, E., Bergvall, C., Westerholm, R., Boman, C., and Pagels, J. H.: Particulate PAH emissions from residential biomass combustion: Time-resolved analysis with aerosol mass spectrometry, Environ. Sci. Technol., 48, 7143-7150, doi:10.1021/es500486j, 2014.

Farmer, D. K., Matsunaga, A., Docherty, K. S., Surratt, J. D., Seinfeld, J. H., Ziemann, P. J., and Jimenez, J. L.: Response of an aerosol spectrometer to organonitrates and organosulfates and implications for atmospheric chemistry, P. Natl. Acad. Sci. USA, 107, 6670-6675, doi:10.1073/pnas.0912340107, 2010.

Fry, J. L., Draper, D. C., Zarzana, K. J., Campuzano-Jost, P., Day, D. A., Jimenez, J. L., Brown, S. S., Cohen, R. C., Kaser, L., Hansel, A., Cappellin, L., Karl, T., Hodzic Roux, A., Turnipseed, A., Cantrell, C., Lefer, B. L., and Grossberg, N.: Observations of gas- and aerosol-phase organic nitrates at BEACHON-RoMBAS 2011, Atmos. Chem. Phys., 13, 8585-8605, doi:10.5194/acp-138585-2013, 2013.

Grieshop, A. P., Donahue, N. M., and Robinson, A. L.: Laboratory investigation of photochemical oxidation of organic aerosol from wood fires 2: analysis of aerosol mass spectrometer data, Atmos. Chem. Phys., 9, 2227-2240, doi:10.5194/acp-9-2227-2009, 2009a.

Grieshop, A. P., Logue, J. M., Donahue, N. M., and Robinson, A. L.: Laboratory investigation of photochemical oxidation of organic aerosol from wood fires 1: measurement and simulation of organic aerosol evolution, Atmos. Chem. Phys., 9, 1263-1277, doi:10.5194/acp-9-1263-2009, 2009b.

Hao, L. Q., Kortelainen, A., Romakkaniemi, S., Portin, H., Jaatinen, A., Leskinen, A., Komppula, M., Miettinen, P., Sueper, D., Pajunoja, A., Smith, J. N., Lehtinen, K. E. J., Worsnop, D. R., Laaksonen, A., and Virtanen, A.: Atmospheric submicron aerosol composition and particulate organic nitrate formation in a boreal forestland-urban mixed region, Atmos. Chem. Phys., 14, 1348313495, doi:10.5194/acp-14-13483-2014, 2014.

Hays, M. D., Gullett, B., King, C., and Robinson, J.: Characterization of carbonaceous aerosols emitted from outdoor boilers, Energ. Fuel, 25, 5632-5638, doi:10.1021/ef2012694, 2011.

Heald, C. L., Kroll, J. H., Jimenez, J. L., Docherty, K. S., DeCarlo, P. F., Aiken, A. C., Chen, Q., Martin, S. T., Farmer, D. K., and Artaxo, P.: A simplified description of the evolution of organic aerosol composition in the atmosphere, Geophys. Res. Lett., 37, L08803, doi:10.1029/2010GL042737, 2010.

Hennigan, C. J., Miracolo, M. A., Engelhart, G. J., May, A. A., Presto, A. A., Lee, T., Sullivan, A. P., McMeeking, G. R., Coe, H., Wold, C. E., Hao, W.-M., Gilman, J. B., Kuster, W. C., de Gouw, J., Schichtel, B. A., Collett Jr., J. L., Kreidenweis, S. M., and Robinson, A. L.: Chemical and physical transformations of organic aerosol from the photo-oxidation of open biomass burning emissions in an environmental chamber, Atmos. Chem. Phys., 11, 7669-7686, doi:10.5194/acp-11-7669-2011, 2011.
Heringa, M. F., DeCarlo, P. F., Chirico, R., Tritscher, T., Dommen, J., Weingartner, E., Richter, R., Wehrle, G., Prévôt, A. S. H., and Baltensperger, U.: Investigations of primary and secondary particulate matter of different wood combustion appliances with a high-resolution time-of-flight aerosol mass spectrometer, Atmos. Chem. Phys., 11, 5945-5957, doi:10.5194/acp-11-59452011, 2011.

Heringa, M. F., DeCarlo, P. F., Chirico, R., Lauber, A., Doberer, A., Good, J., Nussbaumer, T., Keller, A., Burtcher, H., Richard, A., Miljevic, B., Prevot, A. S. H., and Baltensberger, U.: Timeresolved characterization of primary emissions from residential wood combustion appliances, Environ. Sci. Technol., 46, 1141811425, doi:10.1021/es301654w, 2012.

Huang, R. J., Zhang, Y., Bozzetti, C., Ho, K. -F., Cao, J. -J., Han, Y., Daellenbach, K. R., Slowik, J. G., Platt, S. M., Canonaco, F., Zotter, P., Wolf, R., Pieber, S. M., Bruns, E. A., Crippa, M., Ciarelli, G., Piazzalunga, A., Schwikowski, M., Abbaszade, G., SchnelleKreis, J., Zimmermann, R., An, Z., Szidat, S., Baltensperger, U., El Haddad, I., and Prevot, A. S. H.: High secondary aerosol contribution to particulate pollution during haze events in China, Nature, 514, 218-222, doi:10.1038/nature13774, 2014.

Jayne, J., Leard, D., Zhang, X., Davidovits, P., Smith, K., Kolb, C., and Worsnop, D.: Development of an aerosol mass spectrometer for size and composition analysis of submicron particles, Aerosol Sci. Technol., 33, 49-70, 2000.

Jimenez, J. L., Jayne, J. T., Shi, Q., Kolb, C.E., Worsnop, D. R., Yourshaw, I., Seinfeld, J. H., Flagan, R. C., Zhang, X., Smith, K. A., Morris, J., and Davidovits, P.: Ambient aerosol sampling with an aerosol mass spectrometer. J. Geophys. Res.-Atmos., 108, 8425, doi:10.1029/2001JD001213, 2003.

Kiender-Scharr, A., Mensah, A. A., Friese, E., Topping, D., Nemiz, E., Prevot, A. S. H., Äijälä, M., Allan, J., Canonaco, F., Canagaratna, M., Carbone, S., Crippa, M., Dall'Osto, M., Day, D. A., De Carlo, P., Di Marco, C. F., Elbern, H., Eriksson, A., Freney, E., Hao, L., Herrmann, H., Hildebrandt, L., Hillamo, R., Jimenez, J. L., Laaksonen, A., McFiggans, G., Mohr, C., O’Dowd, C., Otjes, R., Ovadnevaite, J., Pandis, S. N., Poulain, L., Schlag, P., Sellgri, K., Swietlicki, E., Tiitta, P., Vermeulen, A., Wahner, A., Worsnop, D., and Wu, H.-C: Ubiquity of organic nitrates from nighttime chemistry in the European submicron aerosol, Geophys. Res. Lett., 43, 7735-7744, doi:10.1002/2016GL069239, 2016.

Kokkola, H., Yli-Pirilä, P., Vesterinen, M., Korhonen, H., Keskinen, H., Romakkaniemi, S., Hao, L., Kortelainen, A., Joutsensaari, J., Worsnop, D. R., Virtanen, A., and Lehtinen, K. E. J.: The role of low volatile organics on secondary organic aerosol formation, Atmos. Chem. Phys., 14, 1689-1700, doi:10.5194/acp-14-16892014, 2014.

Kortelainen, A., Joutsensaari, J., Hao, L., Leskinen, J., Tiitta, P., Jaatinen, A., Miettinen, P., Sippula, O., Torvela, T., Tissari, J. Jokiniemi, J., Worsnop, D., Smith, J., Laaksonen, A., and Virtanen A.: Real-time chemical composition analysis of particulate emissions from woodchip combustion, Energ. Fuel, 29, 11431150, doi:10.1021/ef5019548, 2015.

Kortelainen, A., Hao, L., Tiitta, P., Jaatinen, A., Miettinen, P., Kulmala, M., Smith, J. N., Laaksonen, A., Worsnop, D. R., and Virtanen, A.: Sources of particulate organic nitrates in the boreal forest in Finland, Boreal Env. Res., 22, 13-26, 2017. 
Kroll, J. and Seinfeld, J.: Chemistry of secondary organic aerosol: Formation and evolution of low-volatile organics in the atmosphere, Atmos. Environ., 42, 3593-3624, 2008.

Krechmer, J. E., Pagonis, D., Ziemann, P. J., and Jimenez, J. L.: Quantification of Gas-Wall Partitioning in Teflon Environmental Chambers Using Rapid Bursts of Low-Volatility Oxidized Species Generated in Situ, Environ. Sci. Technol., 50, 57575765, 10.1021/acs.est.6b00606, 2016.

Kroll, J. H., Donahue, N. M., Jimenez, J. L., Kessler, S. H., Canagaratna, M. R., Wilson, K. R., Altieri, K. E., Mazzoleni, L. R., Wozniak, A. S., Bluhm, H., Mysak, E. R., Smith, J. D., Kolb, C. E., and Worsnop, D. R.: Carbon oxidation state as a metric for describing the chemistry of atmospheric organic aerosol, Nat. Chem., 3, 133-139, doi:10.1038/NCHEM.948, 2011.

Lambe, A. T., Onasch, T. B., Croasdale, D. R., Wright, J. P., Martin, A. T., Franklin, J. P., Massoli, P., Kroll, J. H., Canagaratna, M. R., Brune, W. H., Worsnop, D. R., and Davidovits, P.: Transitions from functionalization to fragmentation reactions of laboratory secondary organic aerosol (SOA) generated from the $\mathrm{OH}$ oxidation of alkane precursors, Environ. Sci. Technol., 46, 5430-5437, doi:10.1021/es300274t, 2012.

Lamberg, H., Nuutinen, K., Tissari, J., Ruusunen, J., Yli-Pirilä, P., Sippula, O., Tapanainen, M., Jalava, P., Makkonen, U., Teinilä, K., Saarnio, K., Hillamo, R., Hirvonen, M.-R., and Jokiniemi, J.: Physicochemical characterization of fine particles from smallscale wood combustion, Atmos. Environ., 5, 7635-7643, 2011.

Lanz, V. A., Alfarra, M. R., Baltensperger, U., Buchmann, B., Hueglin, C., and Prevot, A. S. H.: Source apportionment of submicron organic aerosols at an urban site by factor analytical modelling of aerosol mass spectra, Atmos. Chem. Phys., 7, 15031522, 2007.

Lanz, V. A., Prévôt, A. S. H., Alfarra, M. R., Weimer, S., Mohr, C., DeCarlo, P. F., Gianini, M. F. D., Hueglin, C., Schneider, J., Favez, O., D’Anna, B., George, C., and Baltensperger, U.: Characterization of aerosol chemical composition with aerosol mass spectrometry in Central Europe: an overview, Atmos. Chem. Phys., 10, 10453-10471, doi:10.5194/acp-10-10453-2010, 2010.

Leskinen, J., Ihalainen, M., Torvela, T., Kortelainen, M., Lamberg, H., Tiitta, P., Jakobi, G., Grigonyte, J., Joutsensaari, J., Sippula, O., Tissari, J., Virtanen, A., Zimmermann, R., and Jokiniemi, J.: Effective density and morphology of particles emitted from small-scale combustion of various wood fuels, Environ. Sci. Technol., 48, 13298-13306, doi:10.1021/es502214a, 2014.

Leskinen, A., Yli-Pirilä, P., Kuuspalo, K., Sippula, O., Jalava, P., Hirvonen, M.-R., Jokiniemi, J., Virtanen, A., Komppula, M., and Lehtinen, K. E. J.: Characterization and testing of a new environmental chamber, Atmos. Meas. Tech., 8, 2267-2278, doi:10.5194/amt-8-2267-2015, 2015.

Lin, W., Xu, X., Ge, B., and Liu, X.: Gaseous pollutants in Beijing urban area during the heating period 2007-2008: variability, sources, meteorological, and chemical impacts, Atmos. Chem. Phys., 11, 8157-8170, doi:10.5194/acp-11-8157-2011, 2011.

Liu, P., Deng, R., Smith, K., Williams, L., Jayne, J., Canagaratna, M., Moore, K., Onasch, T., Worsnop, W., and Deshler, T.: Transmission efficiency of an aerodynamic focusing lens system: comparison of model calculations and laboratory measurements for the Aerodyne Aerosol Mass Spectrometer, Aerosol. Sci. Technol., 41, 721-733, 2007.
Liu, C., Zhang, P., Yang, B., Wang, Y., and Shu, J.: Kinetic studies of heterogeneous reactions of polycyclic aromatic hydrocarbon aerosols with $\mathrm{NO}_{3}$ radicals, Environ. Sci. Technol. 46, 75757580, doi:10.1021/es301403d, 2012.

McDonald, J., Zielinska, B., Fujita, E., Sagebiel, J., Chow, J., and Watson, J.: Fine particle and gaseous emission rates from residential wood combustion, Environ. Sci. Technol., 34, 20802091, doi:10.1021/es9909632, 2000.

McMurry, P. H. and Grosjean, D.: Gas and aerosol wall losses in teflon film smog chambers, Environ. Sci. Technol., 19, 1176$1182,1985$.

Ng, N. L., Canagaratna, M. R., Zhang, Q., Jimenez, J. L., Tian, J., Ulbrich, I. M., Kroll, J. H., Docherty, K. S., Chhabra, P. S., Bahreini, R., Murphy, S. M., Seinfeld, J. H., Hildebrandt, L., Donahue, N. M., DeCarlo, P. F., Lanz, V. A., Prévôt, A. S. H., Dinar, E., Rudich, Y., and Worsnop, D. R.: Organic aerosol components observed in Northern Hemispheric datasets from Aerosol Mass Spectrometry, Atmos. Chem. Phys., 10, 46254641, doi:10.5194/acp-10-4625-2010, 2010.

Ng, N. L., Canagaratna, M. R., Jimenez, J. L., Chhabra, P. S., Seinfeld, J. H., and Worsnop, D. R.: Changes in organic aerosol composition with aging inferred from aerosol mass spectra, Atmos. Chem. Phys., 11, 6465-6474, doi:10.5194/acp-11-64652011, 2011.

Nguyen, T. B., Bates, K. H., Crounse, J. D., Schwantes, R. H., Zhang, X., Kjaergaard, H. G., Surratt, J. D., Lin, P., Laskin, A., Seinfeld, J. H., and Wennberg, P. O.: Mechanism of the hydroxyl radical oxidation of methacryloyl peroxynitrate (MPAN) and its pathway toward secondary organic aerosol formation in the atmosphere, Phys. Chem. Chem. Phys., 17, 17914, doi:10.1039/c5cp02001h, 2015.

NIOSH Elemental Carbon: (Diesel Particulate) Method 5040, in: NIOSH Manual of Analytical Methods (NMAM), 4th Edn., The National Institute for Occupational Safety and Health: Atlanta, GA, 1999.

Nordin, E., Uski, O., Nyström, R., Jalava, P., Eriksson, A., Genberg, J., Roldin, P., Bergvall, C., Westerholm, R., Jokiniemi, J., Pagels, J., Boman, C., and Hirvonen, M.-R.: Influence of ozone initiated processing on the toxicity of aerosol particles from small scale combustion, Atmos. Environ. 102, 282-289, doi:10.1016/j.atmosenv.2014.11.068, 2015.

Nuutinen, K., Jokiniemi, J., Sippula, O., Lamberg, H., Sutinen J., Horttanainen, P., and Tissari, J.: Effects of air staging on fine particle, dust and gaseous emissions from masonry heater, Biomass Bioenerg., 67, 167-178, doi:10.1016/j.biombioe.2014.04.033, 2014.

Onasch, T. B., Trimborn, A., Fortner, E. C., Jayne, J. T., Kok, G. L., Williams, L. R., Davidovits, P., and Worsnop, D. R.: Soot particle aerosol mass spectrometer: development, validation, and initial application, Aerosol Sci. Technol., 46, 804-817, doi:10.1080/02786826.2012.663948, 2012.

Orasche, J., Seidel, Hartmann, Schnelle-Kreis, J., Chow, J., Ruppert, H., and Zimmermann, R.: Comparison of emissions from wood combustion. Part1: Emission factors and characteristics from different small-scale residential heating appliances considering particulate matter and polycyclic aromatic hydrocarbon (PAH)-related toxicological potential of particle-bound organic species, Energ. Fuel, 26, 6695-6704, doi:10.1021/ef301295k, 2012. 
Orasche, J., Schnelle-Kreis, J., Schön, C., Hartmann, H., Ruppert, H., Arteaga-Salas, J. M., and Zimmermann, R.: Comparison of emissions from wood combustion, Part 2: Impact of combustion conditions on emission factors and characteristic of particle-bound organic species and polycyclic aromatic hydrocarbon (PAH)-related toxicological potential, Energ. Fuel, 27, 1482-1491, doi:10.1021/ef301506h, 2013.

Ortega, A. M., Day, D. A., Cubison, M. J., Brune, W. H., Bon, D., de Gouw, J. A., and Jimenez, J. L.: Secondary organic aerosol formation and primary organic aerosol oxidation from biomass-burning smoke in a flow reactor during FLAME-3, Atmos. Chem. Phys., 13, 11551-11571, doi:10.5194/acp-1311551-2013, 2013.

Ortega, A. M., Hayes, P. L., Peng, Z., Palm, B. B., Hu, W., Day, D. A., Li, R., Cubison, M. J., Brune, W. H., Graus, M., Warneke, C., Gilman, J. B., Kuster, W. C., de Gouw, J., Gutiérrez-Montes, C., and Jimenez, J. L.: Real-time measurements of secondary organic aerosol formation and aging from ambient air in an oxidation flow reactor in the Los Angeles area, Atmos. Chem. Phys., 16, 7411-7433, doi:10.5194/acp-16-7411-2016, 2016.

Paatero, P. and Tapper, U.: Positive matrix factorization: A non-negative factor model with optimal utilization of error estimates of data values, Environmetrics, 5, 111-126, doi:10.1002/env.3170050203, 1994.

Paatero, P.: Least squares formulation of robust non-negative factor analysis, Chemom. Intell. Lab. Syst., 37, 23-35, 1997.

Platt, S. M., El Haddad, I., Zardini, A. A., Clairotte, M., Astorga, C., Wolf, R., Slowik, J. G., Temime-Roussel, B., Marchand, N., Ježek, I., Drinovec, L., Mocnik, G., Möhler, O., Richter, R., Barmet, P., Bianchi, F., Baltensperger, U., and Prévùt, A. S. H.: Secondary organic aerosol formation from gasoline vehicle emissions in a new mobile environmental reaction chamber, Atmos. Chem. Phys., 13, 9141-9158, doi:10.5194/acp-13-91412013, 2013.

Reda, A., Czech, H., Schnelle-Kreis, J., Sippula, O., Orasche, J., Weggler, B., Abbaszade, G., Arteaga-Salas, J., Kortelainen, M., Tissari, J., Jokiniemi, J., Streibel, T., and Zimmermann, R.: Analysis of gas-phase carbonyl compounds in emissions from modern wood combustion appliance: Influence of wood type and combustion appliances, Energ. Fuel, 29, 3897-3907, doi:10.1021/ef502877c, 2015.

Reid, J. S., Koppmann, R., Eck, T. F., and Eleuterio, D. P.: A review of biomass burning emissions part II: intensive physical properties of biomass burning particles, Atmos. Chem. Phys., 5, 799825, doi:10.5194/acp-5-799-2005, 2005.

Rollins, A. W., Browne, E. C., Min, K.- E., Pusede, S. E., Wooldridge, P. J., Gentner, D. R., Goldstein, A. H., Liu, S., Day, D. A., Russell, L. M., and Cohen, R. C: Evidence for $\mathrm{NO}_{x}$ control over nighttime SOA formation, Science, 337, 1210-1212, 2012.

Saarikoski, S., Timonen, H., Saarnio, K., Aurela, M., Järvi, L., Keronen, P., Kerminen, V.-M., and Hillamo, R.: Sources of organic carbon in fine particulate matter in northern European urban air, Atmos. Chem. Phys., 8, 6281-6295, doi:10.5194/acp-86281-2008, 2008.

Schneider, J., Weimer, S., Drewnick, F., Borrmann, S., Helas, G., Gwaze, P., Schmid, O., Andreae, M. O., and Kirchner, U.: Mass spectrometry analysis and aerodynamic properties of various types of combustion-related aerosol particles, Int. J. Mass. Spect. 258, 37-49, 2006.

Seinfeld, J. H. and Pandis S. N.: Atmospheric Chemistry and Physics: From Air Pollution to Climate Change, 2nd Edn., J. Wiley \& Sons, New York, 2006.

Simoneit, B. and Elias, V. O.: Detecting organic tracers from biomass burning in the atmosphere, Mar. Pollut. B., 42, 805-810, 2001.

Sippula, O., Hytönen, K., Tissari, J., Raunemaa, T., and Jokiniemi, J.: Effect of wood fuel on the emissions from a top-feed pellet stove, Energ. Fuel, 21, 1151-1160, 2007.

Sippula, O., Hokkinen, J., Puustinen, H., Yli-Pirilä, P., and Jokiniemi, J.: Particle emissions from small woodfired district heating units, Energ. Fuel, 23, 2974-2982, doi:10.1021/ef900098v, 2009.

Slowik, J. G., Stroud, C., Bottenheim, J. W., Brickell, P. C., Chang, R. Y.-W., Liggio, J., Makar, P. A., Martin, R. V., Moran, M. D., Shantz, N. C., Sjostedt, S. J., van Donkelaar, A., Vlasenko, A., Wiebe, H. A., Xia, A. G., Zhang, J., Leaitch, W. R., and Abbatt, J. P. D.: Characterization of a large biogenic secondary organic aerosol event from eastern Canadian forests, Atmos. Chem. Phys., 10, 2825-2845, doi:10.5194/acp-10-2825-2010, 2010.

Stephens, M., Turner, N., and Sandberg, J.: Particle Identification by Laser-Induced Incandescence in a Solid-State Laser Cavity, Appl. Opt., 42, 3726-3736, 2003.

Taira, M. and Kanda, Y.: Continuous generation system for low concentration gaseous nitrous acid, Anal. Chem., 62, 630-633, 1990.

Tissari, J., Hytönen, K., Lyyränen, J., and Jokiniemi, J.: A novel field measurement method for determine fine particle gas emissions from residential wood combustion, Atmos. Environ. 41, 8330-8344, 2007.

Tissari, J., Lyyränen, J., Hytönen, K., Sippula, O., Tapper, U., Frey, A., Saarnio, K., Pennanen, A. S., Hillamo, R., Salonen, R. O., Hirvonen, M.-R., and Jokiniemi, J.: Fine particle and gaseous emissions from normal and smouldering wood combustion in a conventional masonry heater, Atmos. Environ. 42, 7862-7873, 2008.

Torvela, T., Tissari, J., Sippula, O., Kaivosoja, T., Leskinen, J., Virén, A., Lähde, A., and Jokiniemi, J.: Effect of wood combustion conditions on the morphology of freshly emitted fine particles, Atmos. Environ. 87, 65-76, doi:10.1016/j.atmosenv.2014.01.028, 2014.

Ulbrich, I. M., Canagaratna, M. R., Zhang, Q., Worsnop, D. R., and Jimenez, J. L.: Interpretation of organic components from Positive Matrix Factorization of aerosol mass spectrometric data, Atmos. Chem. Phys., 9, 2891-2918, doi:10.5194/acp-9-2891-2009, 2009.

Vakkari, V., Kerminen, V.-M., Beukes, P., Tiitta, P., van Zyl, P., Josipovic, M., Venter, A., Jaars, K., Worsnop, D., Kulmala, M., and Laakso, L.: Rapid changes in burning aerosols by atmospheric oxidation, Geophys. Res. Lett., 41, 2644-2651, doi:10.1002/2014GL059396, 2014.

Weimer, S., Alfarra, M. R., Schreiber, D., Mohr, M., Prevot, A. S. H., and Baltensperger, U.: Organic aerosol mass spectral signatures from wood-burning emissions: Influence of burning conditions and wood type, J. Geophys. Res., 113, D10304, doi:10.1029/2007JD009308, 2008.

Weitkamp, E., Sage, A., Pierce, J., Donahue, N., and Robinson, A.: Organic aerosol formation from photochemical oxidation of 
diesel exhaust in a smog chamber, Environ. Sci. Technol., 41, 6969-6975, doi:10.1021/es070193r, 2007.

Willis, M. D., Lee, A. K. Y., Onasch, T. B., Fortner, E. C., Williams, L. R., Lambe, A. T., Worsnop, D. R., and Abbatt, J. P. D.: Collection efficiency of the soot-particle aerosol mass spectrometer (SP-AMS) for internally mixed particulate black carbon, Atmos. Meas. Tech., 7, 4507-4516, doi:10.5194/amt-7-4507-2014, 2014.

Ye, P., Ding, X., Hakala, J., Hofbauer, V., Robinson, E. S., and Donahue, N. M.: Vapor wall loss of semi-volatile organic compounds in a Teflon chamber, Aerosol Sci. Technol., 50, 822-834, doi:10.1080/02786826.2016.1195905, 2016.

Yli-Tuomi, T., Siponen, T., Taimisto, P., Aurela, M., Teinilä, K., Hillamo, R., Pekkanen, J., Salonen, R., and Lanki, T.: Impact of wood combustion for secondary heating and recreational purposes on particulate air pollution in a suburb in Finland, Environ. Sci. Technol., 49, 4089-4096, doi:10.1021/es5053683, 2015.
Zhang, Q., Jimenez, J.-L., Canagaratna, M. R., Ulbrich, I. M., Nga, L. N., Worsnop, D. R., and Sun, Y.: Understanding atmospheric organic aerosol via factor analysis of aerosol mass spectrometry: a review, Anal. Bioanal. Chem., 401, 3045-3067, doi:10.1007/s00216-011-5355-y, 2011.

Zhang, X., Cappa, C. D., Jathar, S. H., McVay, R. C., Ensberg, J. J., Kleeman, M. J., and Seinfeld, J. H.: Influence of vapor wall loss in laboratory chambers on yields of secondary organic aerosol, $\mathrm{P}$. Natl. Acad. Sci. USA, 111, 1-6, doi:10.1073/pnas.1404727111, 2014. 